\section{Alternative Management Approaches of Citrus Diseases Caused by Penicillium digitatum (Green Mold) and Penicillium italicum (Blue Mold)}

\author{
Usha K. Bhatta* \\ Department of Plant Pathology, University of Georgia, Athens, GA, United States
}

Green mold (Penicillium digitatum) and blue mold (Penicillium italicum) are among the most economically impactful post-harvest diseases of citrus fruit worldwide. Post-harvest citrus diseases are largely controlled with synthetic fungicides such as pyrimethanil, imazalil, fludioxonil, and thiabendazole. Due to their toxic effects, prolonged and excessive application of these fungicides is gradually restricted in favor of safe and more eco-friendly alternatives. This review comprehensively describes alternative methods for the control of $P$. digitatum and $P$. italicum: (a) antagonistic micro-organisms, (b) plant extracts and essential oils, (c) biofungicides, (d) chitosan and chitosan-based citrus coatings, (e) heat treatments, (f) ionizing and non-ionizing irradiations, (g) food additives, and (h) synthetic elicitors. Integrating multiple approaches such as the application of biocontrol agents with food additives or heat treatments have overcome some drawbacks to single treatments. In addition, integrating treatment approaches could produce an additive or synergistic effect on controlling both molds for a satisfactory level of disease reduction in post-harvest citrus. Further research is warranted on plant resistance and fruit-pathogen interactions to develop safer strategies for the sustainable control of $P$. digitatum and $P$. italicum in citrus.

Keywords: green mold, blue mold, citrus, post-harvest diseases, alternative control methods

\section{INTRODUCTION}

The citrus family Rutaceae primarily comprises sweet oranges, mandarins (tangerines), grapefruit, kumquats, lemons, limes, and pummelos. These important fruit crops are cultivated throughout the tropical and subtropical regions and hold an important economic position in the global fruit industry, with global production exceeding 98 million tons (United States Department of Agriculture, 2021). Oranges represent half of the production, followed by mandarins/tangerines, lemons/limes, and grapefruits. China, Brazil, the European Union, and the United States are the top citrus-producing countries (Liu et al., 2017; United States Department of Agriculture, 2021). Global citrus export in 2021 is estimated at 11 million tons, with oranges accounting for over $40 \%$ and mandarins/tangerines around $30 \%$. South Africa is the largest exporter, followed by Turkey and Egypt, and the United States is the seventh-largest exporter (United States Department of Agriculture, 2021). The United States' share in global citrus trade is dropping primarily due to lower oranges exports. The citrus trade consists of two main markets: fresh and processed, in which oranges account for the most production. In addition to huge quantities of fruit juice, byproducts like essential oils, pectin, molasses, blend syrup, and dried pulp are essential components. Citrus flavonoids exhibit anti-cancer and anti-inflammatory properties and are widely used for medicinal purposes (Benavente-Garcia and Castillo, 2008; Talibi et al., 2014; Al-Snafi, 2016). 
Several biotic and abiotic stressors in the post-harvest handling and citrus agroindustry such as picking, packaging, storage, transportation, and stocking have predisposed citrus fruits to mechanical wounds, resulting in the invasion of fruitdecaying microorganisms that cause spoilage, reduction in shelf life and value, and economic losses (Talibi et al., 2014). In general, the citrus fruit rot rate is around $10-30 \%$, though it can increase to $50 \%$ in severe conditions (Ladaniya, 2011; Li et al., 2019; Youssef and Hussien, 2020). Losses from fungal decay of untreated fruits have been estimated as high as $90 \%$ during post-harvest handling and marketing (Smoot et al., 1971).

Of the many post-harvest diseases reported in citrus, two major challenges for the industry are green and blue mold (Kanetis et al., 2007; Talibi et al., 2014). Green mold, caused by Penicillium digitatum Sacc, and blue mold, caused by Penicillium italicum Wehmer, result in substantial economic losses around the globe (Kavanagh and Wood, 1971; Zamani et al., 2009). The $P$. digitatum and $P$. italicum fungi have a short disease cycle ranging from 3 to 5 days at $25^{\circ} \mathrm{C}$ and reproduce one to two billion conidial spores (Holmes and Eckert, 1999; Zhu H. et al., 2019).

$P$. digitatum, a necrotrophic fungus infecting citrus species via mechanical wounds and environmental factors such as cold, wind, insects, and hail, accounts for $\sim 90 \%$ of total post-harvest losses alone (Perez et al., 2017; Zhu et al., 2017; Lin et al., 2019). The pathogen reproduces quickly on fruit surfaces, and its spores are ubiquitous in the atmosphere (Kanetis et al., 2007). The fungus penetrates fruit pericarp cells, spreads to the mesocarp, and invades nearby cells via germ tube (Han et al., 2013). The infected fruit then produces white mycelia and greenish conidia, a characteristic symptoms of green mold (Lin et al., 2019). The mycelium produces enzymes that break down fruit cell walls and initiate shrinkage, resulting in a sunken mummified form (Papoutsis et al., 2019). The infected pericarp and mesocarp cells plasmolyze, causing a soft watery spot, and the fruit is rotted (Han et al., 2013).

In the case of green mold, infection of the adjacent fruit is rare; however, spores may soil fruits. Ruptured oil glands in the wounded tissue emit volatiles (limonene, myrcene, alphapinene, and betapinene), organic acids, and sugar that stimulate conidial germination (Pelser and Eckert, 1977; Droby et al., 2008). P. digitatum produces thermogenic alkaloids, including tryptoquialanine $\mathrm{A}$ and tryptoquialanine $\mathrm{C}$, which are harmful mycotoxins with potential risk to public health (Ariza et al., 2002; de Vilhena Araújo et al., 2019; Costa et al., 2021).

Spores of $P$. italicum are encapsulated in narrow white mycelium bounded by fluffy, water-soaked rind (Holmes and Eckert, 1999; Palou et al., 2002a,b, 2008; Talibi et al., 2014; Papoutsis et al., 2019). The white mycelium grows and digs into the infected tissue, sporulating blue conidia (Louw and Korsten, 2015). P. italicum is a nesting-type pathogen that spreads rapidly in packed containers to infect adjacent fruits (Ladaniya, 2008) even at lower temperatures in cold storage (Whiteside et al., 1993; Palou et al., 2002a; Iqbal et al., 2012, 2017) with reduced water availability (Plaza et al., 2003). Although initial lesions caused by green mold resemble blue mold disease, a thick non-sporulating mycelium limited by decaying peel surrounds green mold spores (Palou et al., 2008; Talibi et al., 2014).
The economic losses caused by green and blue mold in citriculture are minimized using synthetic fungicides such as thiabendazole, imazalil, prochloraz, fludioxonil, and pyrimethanil, which are primarily used as control agents (Chen et al., 2019). The extensive use of synthetic fungicides has caused the proliferation of resistant strains of these phytopathogens and compromised the effectiveness of chemical treatments (Zhang X. et al., 2018; Chen et al., 2020a). Additionally, concerns about soil quality, environmental pollution, risks associated with human health, and accumulation of chemical residues in food have increased (Palou et al., 2008). Therefore, reducing harmful pressures on the environment is a key to creating a sustainable and healthy food system. Thus, an urgent search for safe and effective methods to replace and reduce the use of harmful chemicals to control $P$. digitatum and $P$. italicum is warranted. Alternative approaches and compounds from nonchemical sources are usually much less toxic to humans, safe, and eco-friendly when compared to chemical fungicides. These alternative methods include biological control with antagonistic microbes such as yeast, bacteria, and fungi, bio-fungicides, plant extracts and essential oils, chitosan, food additives and generally regarded as safe (GRAS) salts, synthetic elicitors, and physical methods such as heat or irradiation (Palou et al., 2016; Liu et al., 2017; Palou, 2018; Papoutsis et al., 2019). These approaches alone or combined with two or more methods represent a promising alternative to the existing chemical pesticides and offer a balanced solution for the control of citrus molds and sustainable production (Moraes Bazioli et al., 2019; Hulot and Hiller, 2021). The flow diagram for citrus green and blue mold management practices is shown in Figure 1.

Although several reviews on post-harvest diseases of citrus have been performed to date (Palou, 2009; Talibi et al., 2014; Chen et al., 2019; Moraes Bazioli et al., 2019; Papoutsis et al., 2019), no studies have reviewed all alternatives in a single paper. Further, the effectiveness and performance of these alternatives have not been discussed in detail. In order to fill this gap in the literature, this review paper aims to comprehensively review past and current research on alternative control methods and their successful application, implications for fruit quality, challenges, and future prospects. This review contributes to the literature on choosing appropriate alternative approaches to control post-harvest citrus disease. A wide range of scientific databases (Google Scholar, Scopus, PubMed, and SciELO) was utilized to search for articles on citrus post-harvest disease management. Based on the literature reviewed, a single treatment has been found less effective than two or more alternatives combined. I conclude that two or more alternatives can be combined to reduce disease incidence and extend shelf life of citrus fruits.

\section{ANTAGONISTIC MICRO-ORGANISMS}

Biological control based on the application of antagonistic microorganisms has emerged as one of the most effective methods for controlling $P$. digitatum and $P$. italicum in citrus fruit. These microorganisms provide an effective 


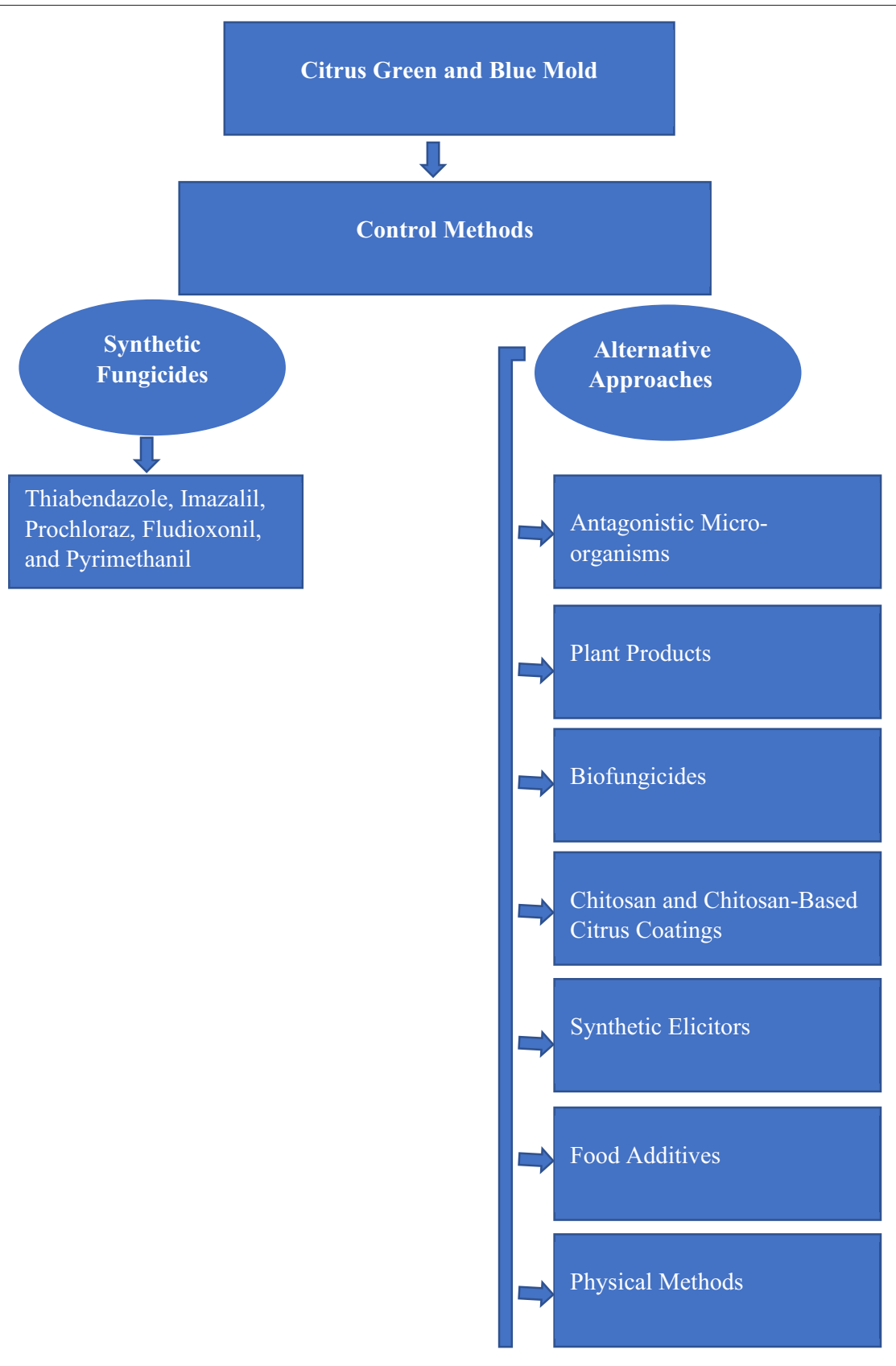

FIGURE 1 | PRISMA flow diagram of the citrus green and blue mold management practices.

eco-friendly choice to chemical fungicides and are easily accepted by consumers (Wilson and Eggemeier, 1991; Droby and Chalutez, 1999; Janisiewicz and Korsten, 2002; Droby et al., 2009). Microbial antagonists display protective and curative action comparable to synthetic fungicides. Antagonistic microorganisms such as yeast, bacteria, and some fungi have been widely used in the biological control of green and blue mold in citrus. An ideal microorganism should be genetically stable, effective at low concentrations, capable of surviving under adverse environmental conditions, inexpensive to formulate and produce, shelf-stable, resistant to common pesticides, compatible with commercial processing practices, and non-pathogenic to human health and the host (Wisniewski and Wilson, 1992). To suppress post-harvest pathogens, these microorganisms provide more than one control mechanisms, such as competition for nutrients and space (Droby et al., 1989, 2002; Panebianco et al., 2015), induction of resistance (Droby et al., 2002), secretion of specific enzymes and toxins and stimulation of secondary metabolism (Bar-Shimon et al., 2004; Luo et al., 2012), biofilm formation (Benhamou, 2004), antibiosis (Nunes et al., 2009), 
and mycoparasitism (Droby et al., 2002). Factors such as $\mathrm{pH}$ of growth media, type of strain used for the control, and time of application, such as pre- or post-harvest affect the efficacy of microbial antagonist (Droby et al., 2002).

Past studies have investigated the use of yeasts to control post-harvest fungal diseases (Platania et al., 2012; Kupper et al., 2013; Moretto et al., 2014; Ferraz et al., 2016; Liu et al., 2017). Yeasts have promising characteristics of pathogenic biocontrol because they infrequently produce antibiotic or mycotoxins substances that could leave residues on fruits (Droby et al., 2002; Gamagae et al., 2004; Zhang et al., 2005). Moreover, yeasts have been studied as antagonists for their inhibitory capacity to colonize surfaces for a long period. Some yeast strains such as Wickerhamomyces anomalus, Saccharomyces cerevisiae, Rhodotorula minuta, and Aureobasidium pullulans have been reported as "killer yeasts" with a killer phenotype: they produce killer proteins for suppressing pathogen development and deforming fungal hyphae (Comitini et al., 2009; Platania et al., 2012; Aloui et al., 2015; Ferraz et al., 2016). In mandarin oranges, the yeasts $W$. anomalus, Metschnikowia pulcherrima, and A. pullulans increase the activity of peroxidase and superoxide dismutase, thereby reducing the incidence and severity of P. italicum (Parafati et al., 2016). Other promising biocontrol agents against $P$. digitatum and $P$. italicum in citrus are bacteria such as Bacillus subtilis and Streptomyces sp. Bacterial pathogens such as Bacillus can act as antagonists or produce volatile organic compounds (VOCs) that increase plant resistance (Leelasuphakul et al., 2008). Maldonado et al. (2010) reported lemon fruit treated with Streptomyces RO3 metabolites showed fungicidal action and reduced the incidence of $P$. digitatum. Moreover, antifungal compounds such as 3-phenyllactic acid and benzeneacetic acid, 2-propenyl ester isolated from Lactobacillus plantarum IMAU10014 have exhibited antifungal activity against P. digitatum (Wang et al., 2012).

A bacterial strain SG-6 (identified as Paenibacillus polymyxa) was isolated as an endophyte from the root tissue of Sophora tonkinensis, which was highly efficient in reducing $P$. digitatum in citrus (Lai et al., 2012). Similarly, the application of endophytic $P$. polymyxa strain SG-6 in an in-vitro assay inhibited the growth of $P$. digitatum conidia and reduced decay in storage. This bacterium did not impair fruit quality parameters such as total soluble solids, ascorbic acid, titratable acidity, or firmness (Lai et al., 2012). In addition, a strain of Bacillus amyloliquefaciens HF-01, isolated from citrus fruit surfaces, was screened for in vitro antagonism toward $P$. digitatum. The isolate was further evaluated alone on artificially inoculated "Wuzishatangju" mandarin fruit. The isolate was found to perform significantly better than the water control in reducing the incidence of green and blue mold. Moreover, combination of tea saponin and $B$. amyloliquefaciens $\mathrm{Hf}-01$ has been found to significantly improve the biocontrol activity of $B$. amyloliquefaciens HF-01. HF-01 combined with $50 \mu \mathrm{g} \mathrm{mL}^{-1}$ tea saponin was found to provide $90 \%$ control of green and blue mold without impairing any fruit quality parameters (Hao et al., 2011).

In a study by Wang et al. (2021b), citrus fruits with blue mold were treated with VOCs produced by Pseudomonas fluorescens ZX incubated on nutrient agar (NA) and in nutrient broth
(NB). The study revealed that the VOCs from $P$. fluorescens ZX inhibited mycelial growth and conidial germination of $P$. italicum by $42.14 \%$ and $77.86 \%$, respectively. Also, in vivo experiments showed that blue mold disease incidence and lesion size on citrus fruits were significantly suppressed by VOCs from $P$. fluorescens ZX incubated on NA, in NB, and on healthy fruits. Similarly, in vitro testing suggested organic acids and sulfur compounds were the active components of VOCs, with dimethyl disulfide and dimethyl trisulfide exhibiting the highest antifungal activity.

Studies have also examined the combined effect of multiple biocontrol agents: either different bacterial strains or bacteria with yeast/fungi, resulting in effective inhibition of citrus molds. For instance, the combined application of Pseudomonas and Trichoderma resulted in significant inhibition of $P$. digitatum on oranges and lemons (Panebianco et al., 2015). In addition, Meziane et al. (2006) investigated Serratia plymuthica, strains IC1270 and IC14 separately and in combination for inhibiting $P$. digitatum or $P$. italicum on oranges. A higher disease suppression and efficacy were observed when combined two bacterial strains $\left(1 \times 10^{8}\right.$ cells $\left./ \mathrm{mL}\right)$. Nutrient competition is considered the primary mode of action in strain IC1270, while antagonism requires a direct cell-to-cell interaction between IC14 and the pathogen.

Similarly, with the aim to inhibit mold and extend storage life in Citrus reticulata Blanco ("Xinyu" tangerine), one study immersed a biocontrol bacterium Paenibacillus brasilensis YS1 into Xinyu tangerines. Xinyus soaked with $P$. brasilensis YS-1 for 10 min showed increased activity of peroxidase, superoxide dismutase (SOD), phenylalanine ammonia-lyase (PAL), and polyphenol oxidase (PPO) in comparison to the control water. This result shows that the post-harvest application of $P$. brasilensis YS-1 can control post-harvest decay, increase defensive enzyme activity, and maintain fruit quality (Chen et al., 2020c).

A few well-known fungal antagonists prove as effective as yeast and bacteria in controlling citrus mold diseases. Antagonistic fungi such as Muscodor albus and Verticillium lecanii produce volatile antimicrobial compounds that control $P$. digitatum decay (Benhamou, 2004; Mercier and Smilanick, 2005). Biofumigant $M$. albus has been used to fumigate lemons in storage to inhibit green mold (Mercier and Smilanick, 2005). Another study explored biocontrol activity of an entomopathogenic fungus $V$. lecanii on the pathogen $P$. digitatum at the cellular level (Benhamou, 2004). Treatment with $V$. lecanii in infected exocarp tissue had dramatic cellular changes characterized by rapid necrotization of the host exocarp cells with severely collapsed hyphae. This finding led to the hypothesis that molds exhibit fungus protection thanks to their direct antimicrobial properties and fruit-induced resistance (Benhamou and Brodeur, 2001). Some endophytic fungi produce volatile antifungal substances (Dennis and Webster, 1971; Strobel et al., 2001; Ezra et al., 2004). For instance, a fungus identified as Nodulisporium sp. CMU-UPE34 produced volatile antifungal compounds, namely alcohols, acids, esters, and monoterpene, with eucalyptol in the greatest abundance. In vitro tests showed the fungus killed a dozen different plant pathogens. In vivo mycofumigation with jasmine rice cultures of Nodulisporium spp. CMU-UPE34 was found to control decay by P. digitatum 
on Citrus limon and by P. italicum on Citrus aurantifolia (Suwannarach et al., 2013).

Combination with other treatment methods such as physical treatments, salts, and elicitors can boost the competency of biological control agents against citrus molds: Candida membranifaciens combined with ultraviolet irradiation and hot-water brushing (Terao et al., 2017); Cryptococcus laurentii with methyl jasmonate (MeJA) (Guo et al., 2014); Kluyveromyces marxianus with sodium bicarbonate (Geng et al., 2011); Saccharomycopsis crataegensis with sodium bicarbonate (Pimenta et al., 2010; see Table 1 for details). In recent work, Wang et al. (2021a) studied the joint application of Meyerozyma guilliermondii and an alginate oligosaccharide (bioactive compound from brown algae) as an effective method of controlling $P$. italicum on mandarin fruit. The study found that a combination of alginate oligosaccharide and M. guilliermondii provided better control than either treatment alone.

Citrus fruits can be infected either prior to harvest or during harvesting and processing; however, most studies on biocontrol agents have examined the post-harvest period, and only a few have studied the pre-harvest period. More work is needed on the application of these biocontrol agents before fruit harvest, as the timing of application impacts the effectiveness of the biocontrol agent. Application time is crucial as the biocontrol agent can utilize available nutrients otherwise consumed by the pathogen in the pre-harvest period (Luo et al., 2012; Panebianco et al., 2015; Papoutsis et al., 2019). So far, most studies have examined the antifungal activities of microbial antagonists as a stand-alone product. Results have shown inconsistent performance and control of previously established infections compared to many commercial fungicides (Ippolito and Nigro, 2000; Zheng et al., 2005). Integrated approaches combining biological control with other methods such as salts or food additives, physical treatments, and non-chemical elicitors or plant growth regulators are one of the most promising means of disease management (Huang et al., 1995; Droby et al., 1998; ElGhaouth et al., 2000; Arras et al., 2002; Janisiewicz and Korsten, 2002; Porat et al., 2002; Zhang et al., 2004; Papoutsis et al., 2019). Overall, an integrated approach facilitates additive, synergistic, complementary, preventive, curative effects on citrus molds while minimizing fungicidal residues (Palou et al., 2008; Smilanick et al., 2008).

\section{NATURAL PLANT PRODUCTS}

In recent years, plant extracts, essential oils, and natural compounds have been evaluated as an alternative chemical means for controlling citrus post-harvest decay (Table 2). More than 1,340 plant species are documented sources of antimicrobial compounds and novel botanical fungicides (Cowan, 1999; Tripathi and Dubey, 2004). Plant extracts are biodegradable, nonphytotoxic, generally safe for human health and the environment, inexpensive, and equally effective as chemical fungicides. Some phytochemicals of plant origin have been successfully formulated as botanical pesticides in integrated pest management programs (Tripathi et al., 2004). Plant extracts and essential oils obtained from medicinal and aromatic plants have effectively controlled agar plates (Ameziane et al., 2007) and wounded citrus fruits (Wilson et al., 1997; Mari and Guizzardi, 1998; Talibi et al., 2012). Plants contain secondary compounds such as acetaldehyde, ethanol, ethyl formate, ethyl benzoate, benzaldehyde, methyl salicylate, eugenol, jasmonates, glucosinolates, hexanal, thymol, allicin, isothiocyanates, citral, limonene, and a variety of phenolic compounds (for example, flavanones, polymethoxylated flavones, and coumarins) that possess antifungal property. These compounds have been derived from plants such as mint, cinnamon, thyme, clove, garlic, oregano, pomegranate, Acacia sp., Aloe sp., and citrus fruits (Utama et al., 2002; Tripathi and Dubey, 2004; Palou et al., 2008).

Plant extracts are known for their preservative, antimicrobial, and antifungal properties. Several studies have investigated aqueous plant extracts and organic solvent extracts against citrus post-harvest pathogens. Plant extracts from species Withania somnifera and Acacia seyal have resulted in the inhibition of $P$. digitatum in citrus by up to $70 \%$ under storage conditions (Samson, 1984). Similarly, flavonone pinocembroside compounds obtained from the fruit of Ficus hirta Vahl. have shown antifungal activity against $P$. italicum in "Navel" oranges by direct inhibition of mycelial growth via membrane targeting (Chen et al., 2020d). In addition, secondary compounds such as acetaldehyde, benzaldehyde, cinnamaldehyde, ethanol, benzyl alcohol, nerolidol, and 2-nonanone have shown effectiveness against P. digitatum (Utama et al., 2002). Citral, an active compound produced in the flavedo of citrus induced a strong defense mechanism against $P$. digitatum inhibiting mycelial growth and spore germination (Rodov et al., 1995; Klieber et al., 2002; Fisher and Phillips, 2008). Methanol extracts from Sanguisorba minor and Cistus villosus showed satisfactory control of P. digitatum (Ameziane et al., 2007; Gatto et al., 2011).

Likewise, in vitro and in vivo assays have demonstrated the capacity of 7-geranoxy coumarin, a natural compound of grapefruit, to act against $P$. digitatum and $P$. italicum (Agnioni et al., 1998). A recent study examined the antifungal potential of pinocembrin-7-glucoside (P7G) isolated from Ficus hirta Vahl. against $P$. italicum. The in vivo test showed $\mathrm{P} 7 \mathrm{G}$ significantly inhibited mycelial growth in artificially inoculated "Newhall Navel" oranges. Further, P7G triggered a marked decline in both chitin and glucanase contents of $P$. italicum mycelia and destroyed the cell wall structure (Chen et al., 2020b). Ethyl extracts such as Chinese propolis ethyl acetate extract (PEAE) have been assessed to control $P$. digitatum and $P$. italicum on post-harvest citrus fruits. Studies show that PEAE strongly inhibited spore germination and mycelium growth, induced unusual morphological alterations, and reduced decay caused by $P$. digitatum and P. italicum on "Zhongqiu" mandarins (Yang et al., 2010). Recently, Zhu H. et al. (2019) investigated the antifungal activity of tannins, a natural polyphenolic compound on $P$. digitatum. In vivo tests showed a significant reduction of $P$. digitatum symptoms in artificially inoculated citrus fruit in storage conditions. The study demonstrated that the antifungal mechanism of tannic acid resulted in the disruption of the cell walls and the plasmatic membrane, causing leakage of intracellular contents such as sugars. 
TABLE 1 | Antagonistic microorganisms for the control of $P$. digitatum and $P$. italicum.

Yeasts
Candida membranifaciens combined with
hot water brushing and ultraviolet
irradiation
Yeast isolates B13 and grape

Yeast isolates B13 and grape

Rhodotorula glutinis

Oranges

Cryptococcus laurentii with methyl jasmonate (MeJA)

Kluyveromyces marxianus with sodium bicarbonate

Rhodosporidium paludigenum (possess broad-spectrum antifungal effects) with ammonium molybdate

Pichia membranefaciens

Saccharomycopsis crataegensis + sodium bicarbonate

Pichia galeiformis (BAF03)

Saccharomyces cerevisiae ACBL-82 strain ACBL-76 strain, Candida stellimalicola ACBL-84 strain ACBL-87 strain Meyerozyma caribbica ACBL-86 strain

Pichia membranaefaciens combined with salicylic acid (SA)

Citrus sinensis L. Osbeck cv. Jincheng 447

Mandarins (Citrus reticulata Blanco cv. Ponkan)

Citrus reticulata Blanco $\quad P$. digitatum cv. Wuzishatangju

Satsuma mandarins

P. digitatum

Citrus sinensis Osbeck cv. Jincheng

Oranges

Oranges, lemons

P. digitatum

Orange fruits (Citrus sinensis cv. Lima)

P. digitatum

and P. italicum

P. digitatum

Yer

Yeast and sodium bicarbonate alone lowered the

$P$. digitatum SA increased the yeast population in fruit wounds, and facilitated P. membranaefaciens growth, and P. italicum promoted nutrient and space competition. $P$.

Candida famata

Oranges

P. digitatum and the wounds

Candida saitoana with $0.2 \%$ glycolchitosan

Oranges, lemons

P. digitatum

Guoqing 1, Owari, Ponkan, and Newhall Navel Orange
P. digitatum Competition for nutrients and space

and P. italicum

P. italicum

Kloeckera apiculata disease severity by $41.7 \%$ and $19.8 \%$, respectively. The combined applications impeded symptoms development from 2 to 10 days

Compete for space and nutrients Production of volatile organic compounds

S. cerevisiae ACBL-82 strain, C. stellimalicola ACBL-84 strain, ACBL-87, and S. cerevisiae ACBL-76 inhibited more than $80 \%$ of pathogen mycelial growth in vitro. M. caribbica ACBL-86 strain, S. cerevisiae ACBL-82 strain decreased disease severity, and blocked green mold incidence in Lima sweet oranges membranaefaciens in combination with SA effectively enhanced the synthesis of phenylalanine ammonia-lyase, chitinase, peroxidase, $\beta$-1,3-glucanase, polyphenoloxidase, and phenolics

Induced resistance and stimulated the fruit to produce phytoalexins (scoparone and scopoletin). Enhanced rapid colonization of the fungal mycelium

Increased competition for nutrients and space. Glycolchitosan has antifungal and film-forming properties

References

Terao et al., 2017

Abraham et al., 2010 decay of lemons and navel oranges, and $<5 \%$

incidence on Valencia oranges, compared to $>50 \%$ nce in untreated fruits

Zheng et al., 2005

Guo et al., 2014

natural resistance in fruit inoculated with $P$. digitatum. Greater activity of peroxidase, catalase, expression level of PR5 (pathogenesis-related

Compete with pathogens for nutrients and space.

Geng et al., 2011

Lu et al., 2018

Luo et al., 2012

Pimenta et al., 2010

Chen et al., 2020f, 2021

da Cunha et al., 2020

Zhou et al., 2014; Spadaro and Droby, 2016

Arras, 1996

El-Ghaouth et al., 2000

Long et al., 2007

(Continued) 
TABLE 1 | Continued

\begin{tabular}{|c|c|c|c|c|}
\hline Yeasts & Citrus species & Pathogens & Control mechanisms & References \\
\hline $\begin{array}{l}\text { Wickerhamomyces anomalus, } \\
\text { Metschnikowia pulcherrima, and } \\
\text { Aureobasidium pullulans species with } \\
\text { locust bean gum (LGB) }\end{array}$ & Mandarin fruit & $\begin{array}{l}\text { P. digitatum } \\
\text { and } \\
\text { P. italicum }\end{array}$ & $\begin{array}{l}\text { Competition for nutrients, antibiosis, fruit resistance } \\
\text { induction, and killer activity. } \\
\text { In combination with edible LGB coatings, yeast } \\
\text { strains are effective for the long-term maintenance } \\
\text { of biocontrol efficacy and yeast cell viability }\end{array}$ & Parafati et al., 2016 \\
\hline Yarrowia lipolytica & Mandarin oranges & $\begin{array}{l}\text { P. digitatum } \\
\text { and } \\
\text { P. italicum }\end{array}$ & $\begin{array}{l}\text { Induced higher activities of peroxidase, catalase, } \\
\text { polyphenol oxidase, flavonoid, phenylalanine } \\
\text { ammonia lyase compounds, and total phenols, } \\
\text { which activates the defense mechanisms and } \\
\text { improves resistance in mandarins }\end{array}$ & Zhu H. et al., 2019 \\
\hline Candida oleophila & $\begin{array}{l}\text { "Marsh Seedless" } \\
\text { grapefruit, Citrus } \\
\text { sinensis (L.) Osbeck cv. } \\
\text { Jincheng } 447\end{array}$ & $\begin{array}{l}\text { P. digitatum } \\
\text { and } \\
\text { P. italicum }\end{array}$ & $\begin{array}{l}\text { Nutrient competition, site exclusion, fungal cell wall } \\
\text { degradation, resistance induction including } \\
\text { accumulation of phytoalexins (scoparone, } \\
\text { scopoletin, and umbelliferone), and direct } \\
\text { mycoparasitism }\end{array}$ & $\begin{array}{l}\text { Droby et al., 2002; Liu } \\
\text { et al., } 2019\end{array}$ \\
\hline Metschnikowia citriensis & $\begin{array}{l}\text { Citrus sinensis (L.) } \\
\text { Osbeck cv. Jincheng } \\
447\end{array}$ & $\begin{array}{l}\text { P. digitatum } \\
\text { and } \\
\text { P. italicum }\end{array}$ & $\begin{array}{l}\text { Deplete iron, adhesion, biofilm formation, and } \\
\text { induce host resistance }\end{array}$ & Liu et al., 2019 \\
\hline $\begin{array}{l}\text { Saccharomyces cerevisiae with calcium } \\
\text { chloride }\left(\mathrm{CaCl}_{2}\right)\end{array}$ & $\begin{array}{l}\text { Tarocco and Valencia } \\
\text { oranges }\end{array}$ & P. digitatum & $\begin{array}{l}\text { Competition for nutrients, space, and "killer" activity. } \\
\text { Synergistic activity when applied along with } \mathrm{CaCl}_{2}\end{array}$ & Strano et al., 2002 \\
\hline $\begin{array}{l}\text { Cryptococcus laurentii }\left(1 \times 10^{7} \text { cells } / \mathrm{mL}\right) \\
\text { with cinnamic acid }(1.5 \mathrm{mM})\end{array}$ & "Orah" mandarins & P. italicum & $\begin{array}{l}\text { Inhibits spore germination, loss of membrane } \\
\text { integrity, and mycelial growth of } P \text {. italicum. } \\
\text { Competition for nutrient and space }\end{array}$ & Li et al., 2019 \\
\hline Pseudozyma antarctica & $\begin{array}{l}\text { Citrus sinensis (L.) } \\
\text { Osbeck cv. Jincheng } \\
447\end{array}$ & $\begin{array}{l}\text { P. digitatum } \\
\text { and } \\
\text { P. italicum }\end{array}$ & $\begin{array}{l}\text { Fungal cell wall degradation, high lytic enzyme } \\
\text { activity, and direct parasitism }\end{array}$ & Liu et al., 2019 \\
\hline Candida stellimalicola & Valencia sweet orange & P. italicum & $\begin{array}{l}\text { The killer activity is a common biocontrol } \\
\text { mechanism }\end{array}$ & da Cunha et al., 2018 \\
\hline Debaryomyces hansenii & $\begin{array}{l}\text { Grapefruit, Mexican } \\
\text { lime }\end{array}$ & $\begin{array}{l}\text { P. digitatum } \\
\text { and } \\
\text { P. italicum }\end{array}$ & Competition for nutrients and space & $\begin{array}{l}\text { Droby et al., 1989; } \\
\text { Chalutz and Wilson, 1990; } \\
\text { Hernández-Montiel et al., } \\
2010\end{array}$ \\
\hline \multicolumn{5}{|l|}{ Bacteria } \\
\hline $\begin{array}{l}\text { Bacillus amyloliquefaciens HF-01 in } \\
\text { combination with tea saponin }\end{array}$ & $\begin{array}{l}\text { "Wuzishatangju" } \\
\text { mandarin }\end{array}$ & $\begin{array}{l}\text { P. digitatum } \\
\text { and } \\
\text { P. italicum }\end{array}$ & $\begin{array}{l}\text { Colonization and secretion of antifungal peptides or } \\
\text { other antibiotics or proteins by } B \text {. amyloliquefaciens. } \\
\text { Plant growth promotion and systemic resistance }\end{array}$ & $\begin{array}{l}\text { Kim and Chung, 2004; } \\
\text { Wong et al., 2008; Hao } \\
\text { et al., } 2011\end{array}$ \\
\hline Bacillus subtilis & Citrus reticulata Blanco & P. digitatum & $\begin{array}{l}\text { Antibiotics, proteins, secondary metabolites, } \\
\text { enzymes, and volatile organic compounds have an } \\
\text { inhibitory effect on mycelial growth and spore } \\
\text { germination }\end{array}$ & Leelasuphakul et al., 2008 \\
\hline Streptomyces sp. & Oranges & P. digitatum & $\begin{array}{l}\text { In vitro assays revealed competition for nutrients } \\
\text { and space. Production of lytic enzymes acting on } \\
\text { the fungus cell wall by altering growth and presence } \\
\text { of antifungal metabolites }\end{array}$ & Najmeh et al., 2014 \\
\hline Enterobacter cloacae & $\begin{array}{l}\text { "Gold Seal" orange } \\
\text { (Citrus sinensis (L.) } \\
\text { Osbeck) }\end{array}$ & P. digitatum & $\begin{array}{l}\text { Competition for nutrients and space. The E. cloacae } \\
\text { strain produces three volatile organic compounds: } \\
\text { butyl acetate, 4,5-dimethyl-1-hexene, and } \\
\text { phenylethyl alcohol, which inhibit conidial } \\
\text { germination, and hyphal elongation }\end{array}$ & Chen et al., 2016 \\
\hline $\begin{array}{l}\text { Pseudomonas cepacia, Pseudomonas } \\
\text { fluorescens, Pseudomonas corrugata, and } \\
\text { Pseudomonas syringae }\end{array}$ & $\begin{array}{l}\text { Lemon fruit (Citrus } \\
\text { limon) }\end{array}$ & P. digitatum & Antibiosis and competition for nutrients and space & $\begin{array}{l}\text { Smilanick and } \\
\text { Denis-Arrue, } 1992\end{array}$ \\
\hline $\begin{array}{l}\text { Pantoea agglomerans in combination with } \\
\text { sodium bicarbonate }\end{array}$ & Oranges & $\begin{array}{l}\text { P. digitatum } \\
\text { and } \\
\text { P. italicum }\end{array}$ & $\begin{array}{l}\text { The exact mechanism of control is not clear. } \\
\text { Colonization and parasitizing the pathogen through } \\
\text { nutrient competition could be possible mechanisms }\end{array}$ & $\begin{array}{l}\text { Riggle and Klos, } 1972 \text {; } \\
\text { Teixidó et al., } 2001\end{array}$ \\
\hline \multicolumn{5}{|l|}{ Fungi } \\
\hline Muscodor albus & Lemons & P. digitatum & Production of volatile compounds & $\begin{array}{l}\text { Mercier and Smilanick, } \\
2005\end{array}$ \\
\hline Verticillium lecanii & Lemons & P. digitatum & Fruit-induced resistance and antimicrobial activity & Benhamou, 2004 \\
\hline
\end{tabular}

Wickerhamomyces anomalus,

Metschnikowia pulcherrima, and

Aureobasidium pullulans species with

sinensis (L.) Osbeck cv. P. italicum

Citrus sinensis (L.)

Osbeck cV. Jincheng

447

oranges

chloride $\left(\mathrm{CaCl}_{2}\right)$

Cryptococcus laurentii $\left(1 \times 10^{7}\right.$ cells $\left./ \mathrm{mL}\right)$

Pseudozyma antarctica

Citrus sinensis (L.)

Osbeck cv. Jincheng

Valencia sweet orange

Grapefruit, Mexican

and

P. italicum

P. digitatum

and

P. italicum

Antibiotics, proteins, secondary metabolites, ds have an inhibitory effect on mycelial growth and spore

and space. Production of Iytic enzymes acting on the fungus cell wall by altering growth and presence metabolites

elongation

fluorescens, Pseudomonas corrugata, and limon)

Pseudomonas syringae

Pantoea agglomerans in combination with

bicarbonate
Pruit-induced resistance and antimicrobial activity 
TABLE 2 | Plant extracts, essential oils, and natural compounds for the control P. digitatum and P. italicum.

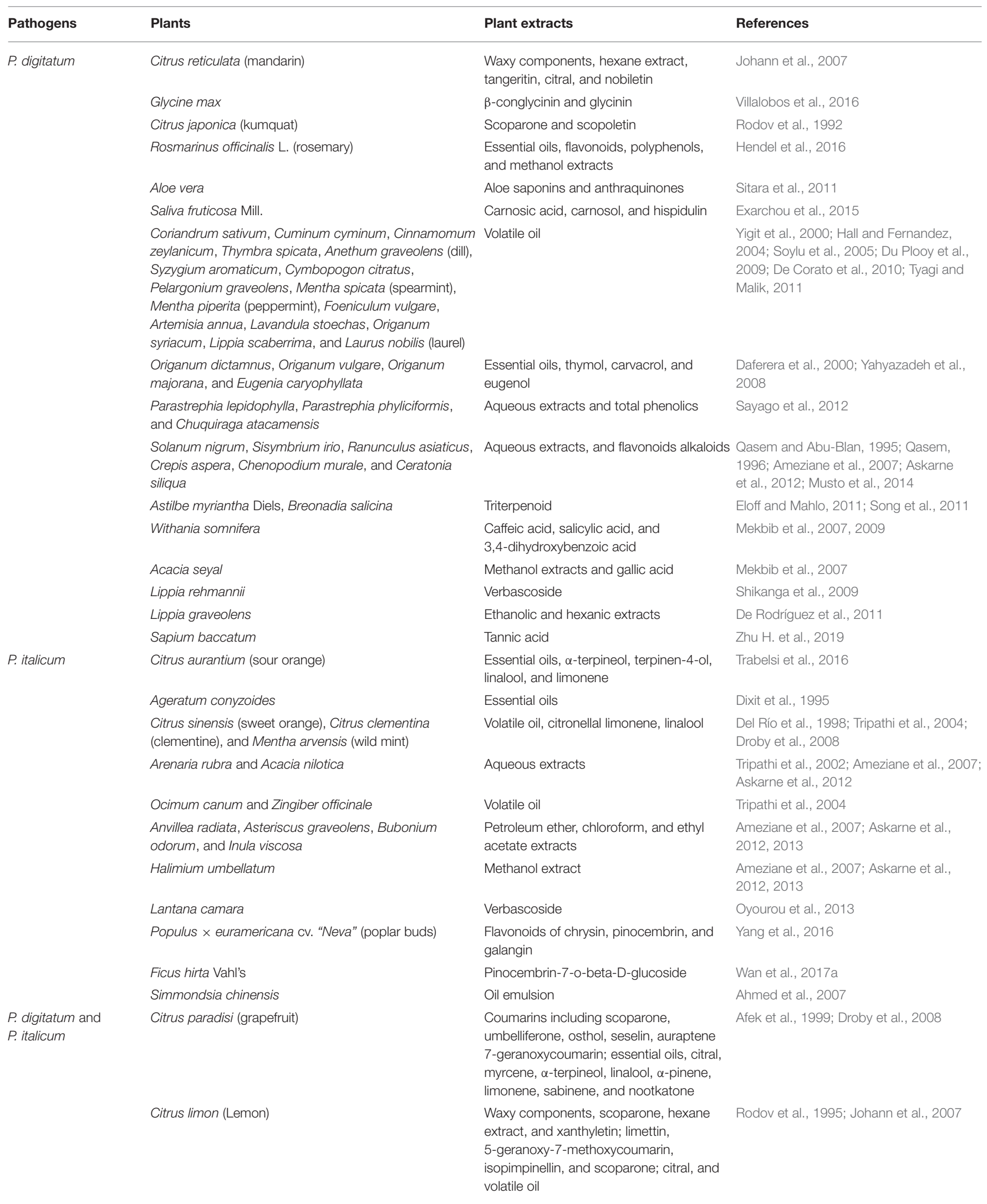


TABLE 2 | Continued

\begin{tabular}{|c|c|c|c|}
\hline Pathogens & Plants & Plant extracts & References \\
\hline & Aloe ferox, Aloe saponaria, and Aloe mitriformis & Aloin & Zapata et al., 2013 \\
\hline & Camellia sinensis & Tea saponins & Hao et al., 2010 \\
\hline & Ramulus cinnamomi & Cinnamaldehyde and cinnamic acid & Wan et al., 2017b \\
\hline & $\begin{array}{l}\text { Melaleuca alternifolia, Zataria multiflora, and Thymus } \\
\text { vulgaris (thyme) }\end{array}$ & Essential oils & $\begin{array}{l}\text { Ramezani et al., 2009; Fatemi et al., 2012; } \\
\text { Zhang X. et al., } 2018\end{array}$ \\
\hline & $\begin{array}{l}\text { Thymus capitatus, Thymus leptobotrys, and Thymus } \\
\text { riatarum }\end{array}$ & Volatile oil, carvacrol, and thymol & $\begin{array}{l}\text { Arras and Usai, 2001; Boubaker et al., } \\
2016\end{array}$ \\
\hline & Cistus villosus & Aqueous extracts & $\begin{array}{l}\text { Ameziane et al., 2007; Askarne et al., } \\
2012\end{array}$ \\
\hline & Thymus satureioides subsp. pseudomastichina & Borneol and thymol & Boubaker et al., 2016 \\
\hline & Peganum harmala & $\begin{array}{l}\text { Harmine, tetrahydroharmine, and } \\
\text { harmaline }\end{array}$ & Kanan and Al-Najar, 2009 \\
\hline & Chinese propolis & $\begin{array}{l}\text { Ethyl acetate extract, methanol, and } \\
\text { pinocembrin }\end{array}$ & $\begin{array}{l}\text { Yang et al., } 2010 \\
\text { Peng et al., } 2012\end{array}$ \\
\hline & $\begin{array}{l}\text { Sonchus oleraceus, Borago officinalis, and Sanguisorba } \\
\text { minor }\end{array}$ & Methanol extract & Gatto et al., 2011 \\
\hline
\end{tabular}

TABLE 3 | Salts and food additives for the control of $P$. digitatum and $P$. italicum.

\begin{tabular}{|c|c|c|c|}
\hline Pathogens & Salts & Fruits & References \\
\hline \multirow[t]{5}{*}{ P. digitatum } & Acetic acid, formic acid, and propionic acid & Grapefruit and oranges & Sholberg, 1998 \\
\hline & Sodium propionate & "Valencia" oranges & Hall, 1988 \\
\hline & Calcium chloride & Grapefruit & Droby et al., 1997 \\
\hline & Calcium polysulfide & Oranges and lemons & Smilanick and Sorenson, 2001 \\
\hline & Potassium sorbate & "Valencia" oranges & Smilanick et al., 2008 \\
\hline \multirow[t]{4}{*}{ P. italicum } & $\begin{array}{l}\text { Sodium salicylate, sodium sulfite, boric acid, copper } \\
\text { sulfate, and sodium ethylenediaminetetraacetic acid }\end{array}$ & $\begin{array}{l}\text { Mandarin (Citrus reticulata Blanco) cv. } \\
\text { clementine }\end{array}$ & Askarne et al., 2013 \\
\hline & Ammonium carbonate & Oranges, lemons & $\begin{array}{l}\text { Askarne et al., 2011; Montesinos-Herrero } \\
\text { et al., } 2011\end{array}$ \\
\hline & Sodium ethylparaben & "Valencia" oranges & Moscoso-Ramírez et al., 2013 \\
\hline & Sodium hydrosulfide & Mandarins and oranges & Fu et al., 2014 \\
\hline \multirow[t]{7}{*}{$P$. digitatum and $P$. italicum } & $\begin{array}{l}\text { Sodium carbonate } \\
\text { Sodium bicarbonate }\end{array}$ & Oranges, mandarins, and lemons & $\begin{array}{l}\text { Plaza et al., 2004b; Youssef et al., 2012b; } \\
\text { Askarne et al., } 2013\end{array}$ \\
\hline & Sodium benzoate & $\begin{array}{l}\text { "Valencia," "Lane Late" oranges, lemons, } \\
\text { and "Ortanique" mandarins }\end{array}$ & $\begin{array}{l}\text { Montesinos-Herrero and Palou, 2016; } \\
\text { Montesinos-Herrero et al., } 2016\end{array}$ \\
\hline & Benzoic acid & Lemons & El-Mougy et al., 2008 \\
\hline & Potassium sorbate & "Valencia" oranges & $\begin{array}{l}\text { Smilanick et al., 2008; D’Aquino et al., } \\
2013\end{array}$ \\
\hline & Sodium metabisulfite and potassium metabisulfite & Oranges & Martínez-Blay et al., 2020 \\
\hline & Sodium dehydroacetate & $\begin{array}{l}\text { "Ponkan" tangerines (Citrus reticulata } \\
\text { Blanco) }\end{array}$ & Duan et al., 2016 \\
\hline & $\begin{array}{l}\text { Calcium chelate } \\
\text { Sodium silicate } \\
\text { Potassium carbonate }\end{array}$ & $\begin{array}{l}\text { "Comune" clementine and "Valencia late" } \\
\text { oranges }\end{array}$ & $\begin{array}{l}\text { Youssef et al., } 2012 b \\
\text { Palou et al., } 2001\end{array}$ \\
\hline
\end{tabular}


TABLE 4 | Physical methods for the control of $P$. digitatum and P. italicum.

\begin{tabular}{|c|c|c|c|c|}
\hline Treatments & Treatment intensity & Cultivars & Pathogens & References \\
\hline \multirow[t]{10}{*}{ Hot water treatment } & Dipping for $5 \mathrm{~min}$ at $50^{\circ} \mathrm{C}$ & Oranges and lemons & P. digitatum & Smoot and Melvin, 1963 \\
\hline & Brief immersions for $2-5 \mathrm{~min}$ at $45-55^{\circ} \mathrm{C}$ & Citrus spp. & $\begin{array}{l}\text { P. digitatum and } \\
\text { P. italicum }\end{array}$ & $\begin{array}{l}\text { Spalding and Reeder, 1986; Couey, } \\
\text { 1989; Rodov et al., } 1995\end{array}$ \\
\hline & $\begin{array}{l}\text { Dipping at } 50-55^{\circ} \mathrm{C} \text { for } 150 \mathrm{~s} \text {, incubated at } \\
20^{\circ} \mathrm{C} \text { for } 7 \text { days }\end{array}$ & Oranges and lemons & $\begin{array}{l}\text { P. digitatum and } \\
\text { P. italicum }\end{array}$ & Palou et al., 2001 \\
\hline & $\begin{array}{l}2-3 \mathrm{~min} \text { hot water dipping at } 50-53^{\circ} \mathrm{C} ; 56^{\circ} \mathrm{C} \\
\text { for } 20 \mathrm{~s} \text {; Hot water rinse brushing (HWRB) at } \\
56^{\circ} \mathrm{C} \text { for } 20 \mathrm{~s} ; 63^{\circ} \mathrm{C} \text { for } 15 \mathrm{~s} ; 62.8^{\circ} \mathrm{C} \text { for } 30 \mathrm{~s}\end{array}$ & Oranges & $\begin{array}{l}\text { P. digitatum and } \\
\text { P. italicum }\end{array}$ & $\begin{array}{l}\text { Schirra et al., 1997; Porat et al., } \\
\text { 2000; Smilanick et al., 2003; Strano } \\
\text { et al., } 2014\end{array}$ \\
\hline & 3 min hot water dipping at $53^{\circ} \mathrm{C}$ & $\begin{array}{l}\text { Pummelo grapefruit hybrid } \\
\text { "Oroblanco" }\end{array}$ & $\begin{array}{l}\text { P. digitatum and } \\
\text { P. italicum }\end{array}$ & Rodov et al., 1995 \\
\hline & $\mathrm{HWRB}$ at $56^{\circ} \mathrm{C}$ for $20 \mathrm{~s}$ & $\begin{array}{l}\text { Tangerines, oranges, and } \\
\text { red grapefruits }\end{array}$ & P. digitatum & Porat et al., 2000 \\
\hline & $\begin{array}{l}\text { Hot water dipping at } 52-53^{\circ} \mathrm{C} \text { for } 2 \mathrm{~min} \text {. HWRB } \\
\text { at } 63^{\circ} \mathrm{C} \text { for } 15 \mathrm{~s}\end{array}$ & Lemons & P. digitatum & $\begin{array}{l}\text { Nafussi et al., 2001; Smilanick et al., } \\
2003\end{array}$ \\
\hline & Hot water treatment at $56-60^{\circ} \mathrm{C}$ for $10 \mathrm{~s}$ & $\begin{array}{l}\text { Pummelo grapefruit hybrid } \\
\text { "Oroblanco" }\end{array}$ & $\begin{array}{l}\text { P. digitatum and } \\
\text { P. italicum }\end{array}$ & Rodov et al., 2000 \\
\hline & $\mathrm{HWRB}$ at $55^{\circ} \mathrm{C}$ for $20 \mathrm{~s}$ & Kumquats & $\begin{array}{l}\text { P. digitatum and } \\
\text { P. italicum }\end{array}$ & Ben-Yehoshua and Porat, 2005 \\
\hline & 3 min hot water dipping at $56^{\circ} \mathrm{C}$ & $\begin{array}{l}\text { Citrus reticulata Blanco } \times \\
\text { Citrus sinensis (L.) Osbeck }\end{array}$ & P. digitatum & Kyriacou, 2011 \\
\hline \multirow[t]{4}{*}{ Curing } & $35^{\circ} \mathrm{C}$ for $72 \mathrm{~h}$ & Washington Navel oranges & $\begin{array}{l}\text { P. digitatum and } \\
\text { P. italicum }\end{array}$ & Tuset, 1987 \\
\hline & $33^{\circ} \mathrm{C}$ for $65 \mathrm{~h}$ & Oranges and lemons & $\begin{array}{l}\text { P. digitatum and } \\
\text { P. italicum }\end{array}$ & Plaza et al., 2003, 2004a \\
\hline & $32^{\circ} \mathrm{C}$ in a saturated water atmosphere for $48 \mathrm{~h}$ & Lemons & P. digitatum & Stange and Eckert, 1994 \\
\hline & $30^{\circ} \mathrm{C}$ with high humidity (90-95\%) for $72 \mathrm{~h}$ & Satsuma mandarins & $\begin{array}{l}\text { P. digitatum and } \\
\text { P. italicum }\end{array}$ & Kinay et al., 2005 \\
\hline \multirow{6}{*}{$\begin{array}{l}\text { Non-ionizing irradiation } \\
\text { and UV-C }\end{array}$} & Fruit exposed to low doses of UV-C irradiation & Marsh seedless grapefruit & P. digitatum & Droby et al., 1993 \\
\hline & UV-C application at doses of $0.5 \mathrm{KJ} \mathrm{m}^{-2}$ & Star Ruby grapefruit & P. digitatum & D’Hallewin et al., 2000 \\
\hline & $\begin{array}{l}\text { Low UV-C irradiation }\left(7.92 \mathrm{~kJ} \mathrm{~m}^{-2}\right) \text { inactivates } \\
\text { spores on the surface of the fruit }\end{array}$ & Oranges & $\begin{array}{l}\text { P. digitatum and } \\
\text { P. italicum }\end{array}$ & Gündüz and Pazir, 2013 \\
\hline & $\begin{array}{l}\text { The antifungal activity of lemon peel extracts } \\
\text { was improved by short-time UV-B irradiation }\end{array}$ & Lemons & P. digitatum & Ruiz et al., 2017 \\
\hline & $\begin{array}{l}210 \text { and } 630 \mu \mathrm{mol} \mathrm{m} \mathrm{m}^{-2} \mathrm{~s}^{-1} \mathrm{LED} \text { blue light } \\
\text { quantum fluxes of boosted scoparone in the } \\
\text { flavedo }\end{array}$ & Oranges & P. digitatum & Ballester and Lafuente, 2017 \\
\hline & $\begin{array}{l}\text { Low-intensity LED blue light irradiation lowered } \\
\text { blue mold symptom development and } \\
\text { suppressed fungal sporulation in satsuma } \\
\text { mandarins }\end{array}$ & Mandarins & P. italicum & Yamaga et al., 2015 \\
\hline
\end{tabular}




\begin{tabular}{|c|c|c|c|c|}
\hline Treatments & Treatment intensity & Cultivars & Pathogens & References \\
\hline \multirow[t]{2}{*}{ Ionizing irradiation } & $\begin{array}{l}510 \text { and } 875 \text { Gy X-ray irradiations decreased } \\
\text { the sporulation of } P \text {. digitatum and } P \text {. italicum } \\
\text { on mandarins that were treated with sodium } \\
\text { carbonate }\end{array}$ & Mandarins & $\begin{array}{l}\text { P. digitatum and } \\
\text { P. italicum }\end{array}$ & Palou et al., 2007 \\
\hline & $\begin{array}{l}1.0 \text { kGy gamma-irradiation demonstrated germ } \\
\text { tube elongation, total inhibition of spore } \\
\text { germination, and mycelial growth of } P \text {. } \\
\text { digitatum }\end{array}$ & Mandarins & P. digitatum & Jeong et al., 2016 \\
\hline \multirow[t]{3}{*}{ Cold storage } & $\begin{array}{l}\text { Temperatures of } 3-5^{\circ} \mathrm{C} \text { and relative humidity of } \\
90-95 \%\end{array}$ & Oranges and mandarins & $\begin{array}{l}\text { P. digitatum and } \\
\text { P. italicum }\end{array}$ & Kader, 2002 \\
\hline & Temperatures of $10-14^{\circ} \mathrm{C}$ & $\begin{array}{l}\text { Lemons, limes, and } \\
\text { grapefruit }\end{array}$ & $\begin{array}{l}\text { P. digitatum and } \\
P . \text { italicum }\end{array}$ & Kader, 2002 \\
\hline & Temperatures of $0-3^{\circ} \mathrm{C}$ & Citrus spp & $\begin{array}{l}\text { P. digitatum and } \\
\text { P. italicum }\end{array}$ & $\begin{array}{l}\text { Tuset, 1987; Snowdon, 1990; Brown } \\
\text { and Eckert, 2000a,b }\end{array}$ \\
\hline \multirow[t]{2}{*}{$\begin{array}{l}\text { Storage in a controlled } \\
\text { atmosphere }\end{array}$} & $5-10 \% \mathrm{O}_{2}+0-5 \% \mathrm{CO}_{2}$ & Oranges and mandarins & $\begin{array}{l}\text { P. digitatum and } \\
P . \text { italicum }\end{array}$ & Kader, 2002 \\
\hline & $5-10 \% \mathrm{O}_{2}+0-10 \% \mathrm{CO}_{2}$ & $\begin{array}{l}\text { Lemons, limes, and } \\
\text { grapefruit }\end{array}$ & $\begin{array}{l}\text { P. digitatum and } \\
P . \text { italicum }\end{array}$ & Kader, 2002 \\
\hline $\begin{array}{l}\text { Storage in ozonated } \\
\text { atmosphere }\end{array}$ & $\begin{array}{l}200 \mu \mathrm{l} / \mathrm{L} \text { ozone gas in humid air with 95\% } \\
\text { relative humidity at } 5^{\circ} \mathrm{C} \text { for } 1 \mathrm{~h}\end{array}$ & Citrus spp & $\begin{array}{l}\text { P. digitatum and } \\
\text { P. italicum }\end{array}$ & Margosan and Smilanick, 1998 \\
\hline
\end{tabular}

The role of plant extracts in combination with alternative treatments such as wax, oil, biocontrol agents, and thermotherapy has been examined against $P$. digitatum and $P$. italicum. For instance, Obagwu and Korsten (2003) tested the water and ethanol extracts of garlic clove alone or in combination with sunflower oil or fruit wax (Obagwu and Korsten, 2003). The authors found all treatment combinations effective; however, a $1 \%$ extract in sunflower oil being the most effective against $P$. digitatum and $P$. italicum in "Valencia" oranges and as effective as fungicides. Sukorini et al. (2013) investigated biofungicidal yeast Candida utilis TISTR 5001 combined with Eugenia caryophyllata crude extract to control $P$. digitatum in tangerines and suggested the application of these extracts as a potential disease management approach. In addition, Koltz et al. (2020) studied the effects of canola and mustard extracts and sachets alone and in combination with thermotherapy to control $P$. digitatum. The study found that the fungitoxic volatile compounds produced with canola and mustard extracts and sachets significantly reduced $P$. digitatum in vitro and in inoculated oranges.

Use of essential oils to control citrus green and blue mold is gaining importance, thanks to antimicrobial and antioxidant properties, synergistic effects, presence of active compounds, and low residue levels (Tripathi and Dubey, 2004; Bakkali et al., 2008). In a study by Chen et al. (2019), the efficacy of clove essential oil (CEO) against $P$. italicum was investigated. Application of CEO was found to inhibit $P$. italicum growth when used at $0.05 \%-0.8 \%(\mathrm{v} / \mathrm{v})$. In addition to its direct antifungal activity, the CEO has demonstrably enhanced the activity of defense-related enzymes such as chitinase and peroxidase to induce host defense responses. Similarly, the influence of numerous essential oils such as lemon grass, eucalyptus, clove, and neem was investigated on "Kinnow" mandarin inoculated with $P$. digitatum and $P$. italicum. The results indicated that these essential oils inhibited both pathogens' growth/colony diameter over untreated PDA plates and reduced decay loss in storage; however, lemon grass oil produced the most potent effect (Jhalegar et al., 2015). Among essential oils, $\mathrm{p}$-anisaldehyde is a naturally occurring and fragrant phenolic compound primarily isolated from anise, cumin, fennel, and garlic. A study was conducted to investigate the antifungal efficiency of p-anisaldehyde on the mycelial growth of $P$. digitatum and $P$. italicum on "Satsuma" mandarin. Panisaldehyde exhibited a robust inhibitory effect on P. digitatum and $P$. italicum leading to altered mycelia morphology, cell wall integrity, and membrane permeability, with minimum inhibitory and fungicidal concentrations of $2.00 \mu \mathrm{l} / \mathrm{ml}$ (Che et al., 2020).

Applying essential oil-amended coatings to citrus is one of several approaches for the control of post-harvest pathogens while maintaining fruit quality. Commercial coatings modified with Lippia scaberrima essential oil achieved $100 \%$ efficacy against $P$. digitatum in "Tomango" oranges (Du Plooy et al., 2009). Yahyazadeh et al. (2009) stated that applying thyme or clove oil to the surface of oranges in polyethylene films lowered $P$. digitatum in vapor-phase experiments at $25^{\circ} \mathrm{C}$. In other research, supplementing carnauba wax with Cinnamomum zeylanicum essential oil $(0.5 \%, \mathrm{v} / \mathrm{v})$ achieved $90 \%$ disease control against post-harvest $P$. digitatum and $P$. italicum in citrus (Kouassi et al., 2012). In addition, citral, a naturally occurring isoprenoid compound with two isomers (geranial and neral), provided antifungal activity against $P$. digitatum in "Navel" oranges (Wolken et al., 2002; Wuryatmo et al., 2003; Droby et al., 2008). Fan et al. (2014) found that citral combined with wax in vitro and in vivo decreased the incidence of $P$. digitatum in "Ponkan" mandarins with significant increases in Vc content and antioxidant enzymes (catalase, SOD, and peroxidase).

Generally, plant products provide antifungal activity and trigger defense mechanisms resulting in cell wall synthesis and elevation of the total soluble phenolic compound concentration 
of orange peels. These products serve as physical and biological barriers to invading pathogens by altering their membrane functionality (Lanciotti et al., 2004; Mekbib et al., 2007). However, the use of natural plant products to inhibit $P$. digitatum and $P$. italicum is in its initial phase as not much is known about their mechanisms of action against post-harvest pathogens. In addition, important limitations with regard to essential oils include potential phytotoxicity, low stability, and induction of strong odors or flavors in treated fruits (Palou et al., 2008; Talibi et al., 2014). More investigations into the mechanisms of such plant products are warranted to control citrus postharvest diseases.

\section{BIOFUNGICIDES}

Biofungicides are formulations of biocontrol microorganisms used against plant diseases (Roger and Keinath, 2010). These fungicides are manufactured in different forms such as wettable powder, emulsion concentrate, suspension concentrate, and tablets, usually for soil drench and application on leaves, seeds, and roots. Biofungicides possess advantages such as low toxicity, low concentrations of active substances, enhanced plant resistance, effective colonization of wounds, nutrient competition, and cost-effectiveness. In 2020, the biofungicides global market was valued at $\$ 1.6$ billion and estimated to grow at a compound annual growth rate of $16.1 \%$ to $\$ 3.4$ billion by 2025 (Matrose et al., 2021).

Some biofungicides used in agricultural production are Binab$\mathrm{T}$ (Trichoderma harzianum and Trichoderma polysporum), Serenada, Baktofit, Kodiak, Rhizo-plus, and Phytosporin (Bacillus subtilis), Phytolavin (Streptomyces griseus), and Planriz (Pseudomonas fluorescens) (Khakimov et al., 2020). Commercial biofungicides based on antagonistic yeasts available on the market to control $P$. digitatum and P. italicum include "Shemer" (Metschnikowia fructicola) (Kurtzman and Droby, 2001), "Aspire" (Candida oleophila) (Liu et al., 2013), and "Pantovital" (Pantoea agglomerans) (Vinas et al., 1998). Likewise, two biofungicidal products based on antagonistic bacteria are "Biosave" (Pseudomonas syringae) (Fravel and Larkin, 1996) and "Natamycin" (Streptomyces sp.) (Chen et al., 2020e). The biofungicide "Shemer" is reported to be as effective against molds in oranges as the chemical fungicide imazalil (Wisniewski et al., 2009; Piombo et al., 2018). The biofungicide "Aspire" has been used commercially but was later reported to have low and inconsistent efficacy (Liu et al., 2013; Spadaro and Droby, 2016).

Aqueous "Natamycin" treatments followed by fruit coating reduced the incidence of decay from $P$. digitatum to $<10 \%$ in grapefruit and lemons compared to the Natamycin untreated control at $81.9 \%$. Moreover, experimental and commercial packing line studies have demonstrated that "Natamycin" mixed with fludioxonil or propiconazole applied as a storage fruit coating or aqueous flooder treatment typically resulted in $>85 \%$ reduction of $P$. digitatum (Chen et al., 2020e). El Guilli et al. (2020) observed the effects of a Pichia guilliermondii strain Z1 granular-formulated product on "Valencia-late" oranges with a suspension of $10^{5}$ conidia/ml of $P$. digitatum and P. italicum at temperatures 4 and $20^{\circ} \mathrm{C}$. Results showed the control achieved with strain Z1 on "Valencia-late" oranges was comparable to that of thiabendazole, indicating the promise of Pichia guilliermondii strain $\mathrm{Z} 1$ as a biofungicide against $P$. digitatum and $P$. italicum. Moreover, the strain $\mathrm{Z} 1$ is compatible with various waxes used in citrus packinghouses (Lahlali et al., 2014).

The major drawback in the commercialization of bioproducts based on biological control agents is the failure to provide consistent and reliable disease control in field experiments. Despite the growing demand for bioproducts, this failure hinders adoption and has slowed dissemination (Spadaro and Droby, 2016; Abbey et al., 2019). While biocontrol products alone do not provide complete control over green and blue molds, enhancements with mixtures of beneficial organisms, integration with low doses of fungicides, and adjustment of storage atmosphere can increase their protective powers (Spotts et al., 2002).

\section{CHITOSAN-BASED CITRUS COATINGS}

One of the most abundant polysaccharides in nature, chitosan is a biodegradable biopolymer obtained from deacetylation of the chitin present in the exoskeleton of crustaceans (e.g., crabs, lobster, shrimp; Hafdani and Sadeghinia, 2011; Talibi et al., 2014; Zhang et al., 2014). It exhibits direct antimicrobial properties against various microorganisms, including fungi, yeasts, and bacteria, and specifically against the post-harvest diseases $P$. digitatum and $P$. italicum in citrus (Palou et al., 2015). Citrus fruits in packing lines are often coated with waxbased compounds amended with conventional fungicides such as imazalil or thiabendazole to reduce weight loss, improve appearance, and control the post-harvest disease. Chitosan and its derivatives are the most-tested antifungal edible coatings to replace commercial waxes against $P$. digitatum and $P$. italicum formulated either alone or with other antifungal ingredients (Palou et al., 2015). The progress of edible antifungal coatings as a safe technology can address post-harvest physiological and pathological problems in citrus.

Past studies have investigated the effectiveness of chitosan to control green mold and blue mold diseases. Panebianco et al. (2014) conducted in vitro and in vivo assays with chitosan applications at $0.02-0.5 \%$ concentration levels against $P$. digitatum. In vitro tests showed that concentrations higher than $0.1 \%$ completely inhibited the pathogen growth. Moreover, in vivo assays demonstrated chitosan application at a concentration of $0.5 \%$ significantly reduced green mold on "Washington Navel", "Valencia" oranges, "Femminello" lemons, and "Marsh Seedless" grapefruits (Panebianco et al., 2014). In another study, El Guilli et al. (2016) investigated the effects of chitosan on green mold and citrus fruit quality by wounding treated fruits with different concentrations of chitosan $24 \mathrm{~h}$ before inoculation with $P$. digitatum. Both in vitro and in vivo results revealed improved antifungal activity against $P$. digitatum with increased chitosan concentrations as well as enhanced chitinase and glucanase activities and elicitation of biochemical defense 
responses without impairing fruit quality. Chitosan not only reduced disease incidence and severity but also enhanced the activities of several enzymes such as SOD, peroxidase, hydrogen peroxide $\left(\mathrm{H}_{2} \mathrm{O}_{2}\right)$, and the levels of glutathione in "Navel" oranges inoculated with P. digitatum and P. italicum (Zeng et al., 2010).

Researchers have explored the antifungal activity of chitosan coatings in combination with other antifungal treatments such as plant extracts, biological control antagonists, salts, and essential oils before or after the application of chitosan-based coatings. ElMohamedy et al. (2015) observed the effects of coatings amended with chitosan and essential oil on citrus fruits as fungicide alternatives to control post-harvest diseases. A combination of chitosan, lemongrass essential oil, citral essential oil, and chitosan-essential oil mixtures significantly reduced the growth and spore germination of $P$. digitatum and $P$. italicum in vitro (El-Mohamedy et al., 2015). Similarly, Shao et al. (2015) observed that chitosan combined with clove oil inhibited $P$. digitatum mycelial growth in Satsuma mandarins in vivo and exhibited high antifungal activity in vitro with stimulation of fruit defense enzymes. Tayel et al. (2016) evaluated fungal chitosan from Mucor rouxii and plant extracts from cress seeds, pomegranate peels, olive leaves, and senna pods. In vitro qualitative and quantitative assays found that all of these agents exhibited antifungal activity against $P$. digitatum and $P$. italicum, resulting in inhibition of fungal growth and viability; however, $P$. digitatum was more resistant than $P$. italicum towards the examined agents (Tayel et al., 2016). In general, chitosan-amended coatings gradually release preservatives and provide additional properties for fruit quality maintenance and fungal growth inhibition (Galed et al., 2004). According to Cháfer et al. (2012), thymol, oil of thyme, has greater antifungal activity against $P$. italicum when incorporated with the chitosan coating on "Powell Navel" oranges without affecting fruit quality attributes.

In recent work, the antifungal activities of carboxymethyl chitosan (CMCS) combined with Cryptococcus laurentii controlled the spore germination of $P$. italicum in grapefruit. Combined treatments of CMCS and C. laurentii exerted a significant synergistic effect resulting in smaller lesion diameter, reduced decay incidence, and stimulation of defense enzyme activities with no impairment of fruit quality parameters (Wang et al., 2019). Likewise, Waewthongrak et al. (2015) evaluated the effect of Bacillus subtilis ABS-S14 endospores, a crude extract from its culture medium, cyclic lipopeptide antibiotics, and chitosan on the suppression of $P$. digitatum in mandarin fruit. Efficacy tests showed a significant reduction of fruit decay and induction of defense-related enzymes such as peroxidase and phenylalanine ammonia-lyase in the infected flavedo tissues. Furthermore, the combination of Candida saitoana with glycolchitosan was more effective in reducing $P$. digitatum infection in lemons and oranges as compared to stand-alone treatments matching the fungicide imazalil in effectiveness (ElGhaouth et al., 2000). Pretreatment with sodium carbonate salts followed with a combination of C. saitoana and glycolchitosan most effectively controlled green mold in light green and yellow lemons (El-Ghaouth et al., 2000).

Research into the combined effects of salicylic acid (SA) and chitosan on the control of $P$. digitatum in grapefruits showed significantly reduced lesion diameter and disease incidence in comparison to applications of chitosan or SA individually. It also enhanced the $\beta$-1,3-glucanase, chitinase, PAL, peroxidase, and PPO activities and stimulated the synthesis of total phenoliccompound content without impairing post-harvest quality (Shi et al., 2018). Besides the use of chitosan and its derivative, several other edible antifungal coatings applied alone or in combination with other treatments were effective against citrus green and blue mold. For instance, Velásquez et al. (2014) observed the effect of pectin-based edible coatings made with essential oil against Penicillium sp. on "Valenica" oranges and found a concentration $1.5 \%$ essential oil reduced decay by $83 \%$ with improved shelf life. Essential oils from Mentha spicata and Lippia scaberrima integrated into commercial citrus waxes also stemmed in protective activity against green mold on "Valencia" and "Tomango" oranges (Du Plooy et al., 2009). Wax coatings not only reduce weight loss in oranges but also maintain overall fruit quality. Formulation of wax coatings with the essential oils carvacrol and thymol reduce green mold incidence and ethylene production in lemons artificially inoculated with $P$. digitatum (Pérez-Alfonso et al., 2012). Moreover, citral incorporated into commercial carnauba wax and applied to citrus fruit showed a concentration 10 times the minimum fungicidal concentration was required to decrease the incidence of $P$. digitatum (Fan et al., 2014). Valencia-Chamorro et al. (2008) developed and optimized hydroxypropyl methylcellulose -lipid edible composite films formulated with food additives or GRAS salts to inhibit the in vitro growth of $P$. digitatum and $P$. italicum. Subsequently, the authors also tested the curative activity of selected coatings in vivo on oranges and mandarins and found that coatings containing the GRAS salts potassium sorbate, sodium benzoate, sodium propionate, and their mixtures most effectively reduced green and blue mold (Valencia-Chamorro et al., 2009).

The quality maintenance and extended shelf life of chitosancoated fruits suggest that chitosan application can partly substitute for synthetic fungicides in commercial storage and marketing (El Guilli et al., 2016). Limited studies exist on combining chitosan with GRAS salts, microbial antagonists, and physical treatment methods to enhance control of citrus decay, and further research is warranted.

\section{SYNTHETIC ELICITORS}

Nowadays, industry favors synthetic chemicals that induce plant immunity and natural disease resistance to activate, bolster, or prime plant defense machinery over biocidal agrochemicals (Droby et al., 2002; Liu et al., 2010; Nantawanit et al., 2010; Zhou and Wang, 2018). The induction of natural resistance to pathogens in harvested fruit using non-toxic chemical elicitors in place of chemical fungicides is a promising and ecologically friendly approach for controlling post-harvest diseases (Zhou and Wang, 2018). Advantages to inducing disease resistance with elicitors include the ability to fight pathogens, lower costs than specific biological antagonists, environmental safety and friendliness, and effectiveness at all stages of fruit development, including preharvest 
and post-harvest (van Hulten et al., 2006; Conrath et al., 2015).

The SA has antifungal properties against specific pathogens in citrus, mango, and pear (Joyce et al., 2001; Shaat and Galal, 2004; Cao et al., 2006). Increasing SA concentrations through the exogenous application or endogenous synthesis stimulates systemic acquired resistance in plants (Verberne et al., 2000). It also delays senescence, retards fruit decay, and facilitates plant growth regulation and interaction with other organisms in response to biotic or abiotic stresses (Yalpani et al., 1994; Senaratna et al., 2000).

The plant hormone MeJA, formed via the octadecanoid pathway together with jasmonic acid (JA) (Holopainen et al., 2009), has been found to mediate diverse developmental processes and defense responses (Cheong and Do Choi, 2003) and enhance the disease resistance (Meng et al., 2009). Similarly, JA is a natural inducer of disease resistance that stimulates antifungal activity in crops such as mango, pear, and citrus fruits and regulates plant growth and development (Shaat and Galal, 2004; Yao and Tian, 2005).

The chemical elicitor $\beta$-aminobutyric acid (BABA) is a nonproteinogenic amino acid that behaves as a safe priming molecule of systemic resistance induction in several crops such as apple, citrus, and strawberry (Conrath et al., 2015; Baccelli et al., 2017; Guolin et al., 2019; Aghdam et al., 2020). In plants, BABA acts on various post-harvest fungi (Wang J. et al., 2018; Cheng et al., 2019) with multiple biochemical and physical defense mechanisms, including the creation of physical barriers (callose, lignin, and papillae), hypersensitivity reaction, accumulation of phytoalexins, induction of pathogenesis-related (PR) proteins, biosynthesis of terpenoids, generation of reactive oxygen species (ROS) with $\mathrm{H}_{2} \mathrm{O}_{2}$ and activation of defense pathways mediated by abscisic acid, SA, and JA (Cohen, 2002; Walters et al., 2013).

Iqbal et al. (2012) studied the effect of two organic elicitors, SA and MeJA, in "Lane Late" sweet orange, including pre- and postharvest application for resistance induction. In vitro experiments with post-harvest treatment showed that $S A \geq 6 \mathrm{mM}$ substantially inhibited the sporulation, radial growth, and spore germination of Penicillium sp. compared to MeJA and control. However, MeJA showed only a suppressive effect on fungal propagules at concentrations $\geq 4 \mathrm{mM}$. In contrast, preharvest spray application of $8 \mathrm{mM} \mathrm{SA}$ and $3 \mathrm{mM}$ MeJA to "Lane Late" orange effectively reduced wound rotting, colony/lesion diameter, and spore mass density of $P$. digitatum. Overall, pre- and post-harvest treatments of fruit with SA proved more effective in lessening mold severity than MeJA.

Similarly, Shaat and Galal (2004) assessed the preharvest spray application of SA on the incidence of $P$. digitatum in grapefruit, lime, mandarin, and six orange cultivars. In general, preharvest application of elicitors proved more effective as it allowed the host to develop more induced resistance and fruit protection than in post-harvest application. In vitro growth inhibition of $P$. digitatum was highest with $400 \mathrm{mg} \mathrm{L}^{-1} \mathrm{SA}$ treatment. A recent study examined the capacity of SA and JA to suppresses $P$. digitatum and P. italicum in post-harvest infection on Citrus reticulata "Kinnow," Citrus limon "Meyer Lemon," and Citrus limetta "Mosambi." SA and JA significantly reduced the severity of $P$. digitatum and $P$. italicum on all tested citrus species compared to the non-treated control. The efficacy of both SA and JA in reducing disease severity depended on concentration; higher concentrations resulted in a greater degree of suppression. Results also showed that SA and JA increase the activity of PPO and peroxidase, which suppressed the development of green and blue mold most effectively in C. reticulata and least so in C. limon (Moosa et al., 2019).

In addition, INA (2,6-dichloroisonicotinic acid), a synthetic analog of SA, was investigated for controlling the post-harvest incidence of $P$. digitatum and $P$. italicum. Treatments of $1.0 \mathrm{mmol}$ $\mathrm{L}^{-1}$ INA significantly reduced green and blue molds on both wound-inoculated and naturally infected fruit compared with the control. Moreover, $\beta$-1,3-glucanase, chitinase, PAL, peroxidase, and PPO can be used to control diseases (Jing et al., 2020).

Elsherbiny et al. (2021) studied the mechanisms and effects of BABA treatment on the inhibition of $P$. digitatum both in orange fruit and in vitro. BABA at $125 \mathrm{mM}$ was found to significantly inhibit spore germination, mycelial growth, and germ tube elongation of $P$. digitatum and suppress disease incidence and disease severity compared to untreated fruit. In accordance with this study, Porat et al. (2003) found that treatments with BABA at $20 \mathrm{mM}$ reduced the incidence of $P$. digitatum in infected wounds on grapefruit. Panebianco et al. (2014) likewise reported that very high concentrations of BABA reduce $P$. digitatum decay on oranges cvs. "Tarocco" and "Valencia" and on grapefruit cv. "Marsh Seedless" by 70-90\%. The fungistatic properties of BABA affect the fungal cell membrane by inhibiting $P$. digitatum growth, increasing cell membrane permeability and malondialdehyde content, and decreasing the ergosterol and the total lipid contents. Similar structural defects have been observed in $P$. digitatum treated with cecropin A-melittin hybrid peptide BP21 (Wang W. et al., 2018), the essential oil of C. reticulata (Tao et al., 2014), and pinocembroside isolated from Ficus hirta Vahl. fruit (Chen et al., 2020d).

As biological control does function across a spectrum as broad as chemical fungicides, combining biocontrol agents with synthetic elicitors can enhance their performance. Zhou et al. (2014) investigated the effects of Pichia membranaefaciens and SA for the control of $P$. digitatum and $P$. italicum in citrus fruit. Combining the yeast with SA effectively enhanced the phenylalanine ammonialyase, peroxidase, polyphenoloxidase, chitinase, and $\beta$-1,3-glucanase activities and synthesis of phenolic compounds without ruining fruit quality parameters. In line with Zhang et al. (2010), these results suggested that SA enhanced the biocontrol efficacy of this yeast in post-harvest diseases by facilitating its growth and promoting nutrient and space competition.

Similarly, Guo et al. (2014) examined the preventive activity of MeJA alone and in combination with the antagonistic yeast $C$. laurentii for preventing green mold in citrus fruit. MeJA alone with a concentration of $100 \mu \mathrm{mol} / \mathrm{L}$ inhibited disease incidence and lesion diameter of mold decay compared with the control or the application of $100 \mu \mathrm{mol} / \mathrm{L}$ combined with $C$. laurentii at $1 \times$ $10^{8}$ cells $/ \mathrm{mL}$. Relative to single-treatment groups and the control, 
MeJA and C. laurentii induced higher peroxidase, polyphenol oxidase, and catalase activity and a rise in the mRNA expression of PR5 (pathogenesis-related protein family 5); it likewise induced natural resistance and stimulated the proliferation of antagonistic yeast on the fruit surface. Additionally, when Zhou et al. (2018) applied SA $\left(2.5 \mathrm{mmol} \mathrm{L}^{-1}\right)$, P. membranaefaciens (1 $\times 10^{8}$ cells $\left.\mathrm{mL}^{-1}\right)$, or oligochitosan $\left(15 \mathrm{~g} \mathrm{~L}^{-1}\right)$, these exogenous elicitors led to effective inhibition of $P$. digitatum and $P$. italicum in pathogen-inoculated citrus fruit. Results indicated that the activation of the phenylpropanoid biosynthesis pathway led to the induction of resistance in citrus fruit.

These studies suggest potential strategies by which combinations of two to three different methods complement each other to suppress post-harvest disease in citrus; however, the results do not fully predict control efficacy under commercial practice. Therefore, additional research under commercial practice is warranted. Because little is known about the combined effects of elicitors on the metabolic pathway and regulatory network of phenylpropanoids in citrus fruit, further study into the interaction of citrus species with Penicillium sp. is needed to understand how different hosts respond to various treatments during storage and commercial application (Louw and Korsten, 2015).

\section{FOOD ADDITIVES}

Food additives, particularly preservatives or substances classified as GRAS by the U.S. Food and Drug Administration are alternatives to conventional fungicides for post-harvest disease control in citrus fruits. The food industry commonly adds organic and inorganic salts to food for the purposes of leavening, $\mathrm{pH}$ control, taste, and texture modification (Smilanick et al., 1999). These compounds also exhibit a broad spectrum of activity against bacteria and fungi. The inorganic salts most widely used to control post-harvest disease in citrus fruit are sodium carbonate, sodium bicarbonate, and potassium sorbate, all classified as GRAS compounds (Table 3). Several other foodgrade preservatives that have proven effective against citrus green and blue mold diseases include sodium paraben salts, sodium benzoate, and potassium silicate (Montesinos and Palou, 2016). Major advantages of using these salts for post-harvest treatment include antimicrobial properties, low toxicity, relatively low cost, ready availability, safety for humans and the environment, and its unrestricted use (El-Mougy et al., 2008; Deliopoulos et al., 2010; Palou, 2016).

In vivo and in vitro studies have demonstrated the high effectiveness of salts such as potassium sorbate and sodium benzoate against $P$. digitatum and $P$. italicum decay in oranges and lemons (Palou et al., 2002a; Montesinos-Herrero et al., 2016). Non-toxic and tasteless sodium benzoate is specifically known for its bactericidal and bacteriostatic properties (El-Mougy et al., 2008). Likewise, in-vivo assays with sodium carbonate, ammonium carbonate, boric acid, copper sulfate, sodium ethylenediaminetetraacetic acid, sodium salicylate, sodium sulfite, and sodium metabisulfite are known to inhibit mycelial growth of $P$. italicum in citrus (Askarne et al., 2013). These salts act against molds through membrane disruption, stresses on $\mathrm{pH}$ homeostasis through anion accumulation within the cell, inhibition of essential metabolic functions, and activation of defense mechanisms in fruits (Smilanick et al., 2005; Youssef et al., 2014). Although these salts provide good control of citrus molds, application time is crucial because salts applied before the harvest period have more time to interact with mold pathogens than after harvest, resulting in greater efficacy (Youssef et al., 2012b).

Post-harvest $P$. digitatum and $P$. italicum incidence on lemons and oranges was effectively controlled by fumigation with ammonia gas not exceeding 6,000 $\mu \mathrm{L} / \mathrm{L}$ (Montesinos-Herrero et al., 2011). Oranges treated with ammonium molybdate and sodium molybdate have shown a significant decrease in the incidence of $P$. digitatum and P. italicum (Palou et al., 2002a). Ammonium molybdate can inhibit acid phosphatase, which interferes with phosphorylation and dephosphorylation and affects metabolic processes in several organisms (Mukhopadhyay et al., 1988; Bodart et al., 1999). Fumigation of mandarins and oranges by hydrogen sulfide salts decreases the growth of $P$. italicum on tested fruit surfaces, inhibiting spore germination through ROS related mechanisms (Fu et al., 2014). Moreover, food preservatives are as successful as salts in controlling citrus molds. Sodium dehydroacetate, a common food preservative, inhibited mycelial growths of $P$. digitatum and $P$. italicum in vivo and in vitro experiments (Duan et al., 2016).

Several salts are known to induce host resistance via stimulation of defense-related genes. Electrolyzed sodium bicarbonate induced oxidative stress in the P. digitatum conidia via accumulation of ROS, the collapse of mitochondrial membrane, disrupted adenosine triphosphate production, and upregulated defense-related gene coding for peroxidase and PAL (Fallanaj et al., 2016). Furthermore, the electrolytes sodium metabisulfite, potassium sorbate, potassium carbonate, and sodium chloride were used to generate alkaline- (alEW), and acidic- (acEW) electrolyzed water for inhibition of $P$. digitatum and $P$. italicum on "Valencia" sweet orange (Youssef and Hussien, 2020).

Several studies conducted to control Penicillium molds suggested the performance of these salts could be enhanced by combining them with other treatments such as antagonistic microorganisms, hot water, low-dose chemical fungicides, and wax coatings (Smilanick et al., 2008; Youssef et al., 2012a). Teixidó et al. (2001) evaluated the potential of Pantoea agglomerans (strain CPA-2) in combination with sodium carbonate or bicarbonate solutions under ambient $\left(20^{\circ} \mathrm{C}\right)$ and cold storage $\left(3^{\circ} \mathrm{C}\right)$ conditions for the control of $P$. digitatum and $P$. italicum. The study detected a $97.6 \%$ reduction of decay incidence with sodium bicarbonate. In addition, Smilanick et al. (1999) observed a significant improvement in the effectiveness of sodium bicarbonate and carbonate when treatments were followed with Pseudomonas syringae ESC-10. The residues of biological control antagonists were found to persist long after treatment, thereby protecting fruit from reinfection.

Moreover, the combined application of marine yeast Rhodosporidium paludigenum and sodium bicarbonate proved as effective as a fungicide, eliminating the decay incidence of 
green mold in citrus fruit (Zhu et al., 2013). Also, Lu et al. (2018) assessed the effectiveness of the combined treatment of ammonium molybdate and $R$. paludigenum to control green mold disease in satsuma mandarin. The addition of $0.1 \mathrm{mmol}$ $\mathrm{L}^{-1}$ ammonium molybdate significantly enhanced the biological activity of $R$. paludigenum against $P$. digitatum, reduced disease incidence by $89.3 \%$, and discontinued mold development within $0-12 \mathrm{~h}$ of infection. Ammonium molybdate depresses the ectophosphate activity of $P$. digitatum, disturbs the environmental acidification of the pathogen, and suppresses spore germination.

Sorbic acid salts (also used as food additives) such as potassium sorbate are classified as minimal-risk active ingredients, similar to chemical fungicides in effectiveness, and appropriate for aqueous application (Smilanick et al., 2008). Heated aqueous solutions were found to enhance the performance of potassium sorbate against green mold. Inhibitory effects of sorbic acid on $P$. digitatum and $P$. italicum include inhibition of enzymes and protein synthesis, alteration of cell-membrane and cell-transport function, and uncoupling of oxidative phosphorylation in mitochondria (El-Mougy et al., 2008). Also, short dip treatments of citrus fruits in salt solutions of $2-3 \%$ have significantly reduced the incidence of $P$. digitatum and P. italicum without causing rind phytotoxicities (Palou, 2016). For instance, dips in sodium metabisulfite and potassium metabisulfite at 20 and $50 \mathrm{mM}$ for 60 or $120 \mathrm{~s}$ at room temperature $\left(20^{\circ} \mathrm{C}\right)$ significantly reduced the incidence and severity of $P$. digitatum and $P$. italicum on "Valencia" oranges (Martínez-Blay et al., 2020). Dip treatments of $60 \mathrm{~s}$ with 3\% sodium benzoate heated above $50^{\circ} \mathrm{C}$ resulted in $90 \%$ reduction of P. digitatum and P. italicum on "Valencia" oranges, "Lanelate" oranges, "Fino" lemons, and "Ortanique" mandarins, offering an important disease control alternative for the commercialization of citrus without fungicidal residues (Montesinos-Herrero et al., 2016).

In addition, Cerioni et al. (2013) investigated the use of potassium sorbate, sodium bicarbonate, and potassium phosphite in combination with heat and $\mathrm{H}_{2} \mathrm{O}_{2}$ in the presence of copper sulfate to control Penicillium molds in lemons. The authors reported phosphite solutions controlled $P$. digitatum only when heated or combined with fungicides. Moreover, combining wax with potassium sorbate salts provided antifungal activity against citrus molds but impaired the film-forming capacity of the wax, eventually resulting in fruit weight loss (Youssef et al., 2012a; Parra et al., 2014). In a study by Youssef et al. (2012a), ammonium bicarbonate was found not to interfere with the capacity of wax to retard weight loss.

Although these treatments offer alternatives to fungicides for post-harvest disease control, concerns regarding dietary safety, disposal, fruit quality parameters, worker safety, and other regulatory issues must be addressed before these compounds gain approval for post-harvest use. For instance, the disposal of sodium bicarbonate raises regulatory issues in some locations because of its high $\mathrm{pH}$, electrical conductivity, and sodium content (Smilanick et al., 2008). Further research from an integrated approach should seek a suitable combination of salts with non-chemical treatments such as wax to improve fruit quality parameters.

\section{PHYSICAL CONTROL METHODS}

Physical treatments are gaining popularity in the control of citrus post-harvest diseases as it leaves no residue and has the least environmental impact than other options (Palou, 2009; Usall et al., 2016). Of the physical technologies so far investigated for reducing $P$. digitatum and $P$. italicum in citrus fruit and prolonging its storage life, the most promising include heat, ultraviolet light (UV-C and UV-B), blue light, x-rays, and gamma irradiation; complementary methods include controlled and modified atmospheres and cold storage (Droby et al., 1993; Nafussi et al., 2001; Kader, 2002; Smilanick et al., 2003; Palou et al., 2007; Gündüz and Pazir, 2013; Lafuente and Alférez, 2015; Jeong et al., 2016; Yamaga et al., 2016; Table 4).

Heat treatments can be applied to citrus fruit via hot water dips and sprays, hot vapor or curing (hot air application), and hot water rinsing and brushing. When infection structures are present on fruit surfaces, heat applied for a short period can easily affect these tissues, inducing several physiochemical changes to achieve a significant degree of control. Factors that determine the effectiveness of heat treatments include the product's condition prior to treatment, type of commodity, temperature, duration of treatment, and mode of heat application. Studies on the performance of water temperatures ranging from 40 to $65^{\circ} \mathrm{C}$ have been conducted (Palou et al., 2002a; García et al., 2016). Hot water treatment (HWT) was found to interrupt fungal spore growth for $24-48 \mathrm{~h}$ by the accumulation of secondary metabolites such as PR proteins, phytoalexins, accumulation of lignins in fruit infected by fungus, and production of ROS contributing to resistance against $P$. digitatum and $P$. italicum in citrus fruit (Nafussi et al., 2001; Yun et al., 2013; Perotti et al., 2015; Sui et al., 2016). Curing is another HWT post-harvest decay control method whereby citrus fruits are exposed for 2-3 days to air atmospheres heated to temperatures higher than $30^{\circ} \mathrm{C}$ at high relative humidity ( $\mathrm{RH}>90 \%$ ) (Palou, 2009). Improper heat treatments such as excessive temperatures and long durations have damaged fruit. For example, $53-55^{\circ} \mathrm{C}$ for $2-3 \mathrm{~min}$. and $60^{\circ} \mathrm{C}$ for $20 \mathrm{~s}$. have led to surface injury and rind browning in oranges (Schirra et al., 1997; Porat et al., 2000; Palou et al., 2001).

Both UV-C and UV-B are non-ionizing irradiations that have been widely studied for the prevention of green and blue mold in citrus. UV-B irradiation has been reported to harm the surface of citrus fruit less than UV-C treatment (Kaewsuksaeng et al., 2011) and at intensities higher than $30 \mathrm{~kJ} \mathrm{~m}^{-2}$ inactivated $P$. digitatum and P. italicum conidia in vitro (Yamaga et al., 2016). Factors determining the effectiveness of UV irradiation include type and intensity, harvesting period, stage of fruit development, and storage temperature (Droby et al., 1993; Yamaga et al., 2016). Overall, UV treatment causes metabolic and anatomical changes and accumulation in citrus flavedo of secondary metabolites such as polyphenols and phytoalexins, which are involved in fruit resistance (Droby et al., 1993; Ruiz et al., 2017). However, high intensities of UV-C irradiation might damage the flavedo of citrus and warrant precautions (Kim et al., 1991). Large-scale studies on UV treatment for citrus decay are needed to make any recommendations for the commercial use of irradiation in post-harvest citrus handling. 
Blue light has the potential to reduce green and blue mold disease during post-harvest storage of citrus. It has been reported that blue light enhances fruit resistance against $P$. digitatum and $P$. italicum by stimulating the production of secondary metabolites and impairing fungal growth (Lafuente and Alférez, 2015; Ballester and Lafuente, 2017). For instance, Liao et al. (2013) found that blue light at a photon fluence rate of $40 \mu \mathrm{mol}$ $\mathrm{m}^{-2} \mathrm{~s}^{-1}$ decreased the symptomatic development of green and blue mold in "Fallglo" tangerine and in vitro fungal growth of $P$. italicum, leading to the induction of defensive responses in the host. In vitro experiments also revealed that the efficacy of blue light increases with the duration of the application and light quantum flux by affecting fungal morphology and sporulation and increasing the phytoalexin scoparone and production of ROS in fungal cell walls (Lafuente and Alférez, 2015; El-Esawi et al., 2017).

Similarly, X-ray and gamma irradiation have been recognized as sustainable methods for extending the post-harvest life of citrus from decay (Rojas-Argudo et al., 2012; Guerreiro et al., 2016). X-ray differs from gamma irradiations in that $X$-rays are concentrated in the same direction as the electron beam while gamma rays are emitted uniformly in all directions (Palou, 2009). Rojas-Argudo et al. (2012) found that X-ray irradiation stimulates rind biosynthesis and synthesis of the phytoalexins scoparone and scopoletin in "Clemenules" mandarins at a storage temperature of $20^{\circ} \mathrm{C}$. X-rays have increased scoparone levels after fruit inoculation in combination with sodium carbonate. The ionizing characteristics of X-ray irradiation was found to cause oxidative stress in fruits, which can influence the bioactive compounds located in fruit tissues and potentially improve the resistance of those fruits to pathogens (Oufedjikh et al., 2000).

Gamma radiation has likewise proven detrimental to fungal physiology by disrupting fungal cell membranes, retarding fruit ripening and respiration rate, and regulating the activity of enzymes (Cia et al., 2007; Schweiggert et al., 2007; Wang et al., 2017). However, Jeong et al. (2016) reported that higher doses may cause severe damage to the surface of citrus. Operating gamma-irradiation at lower doses can exclude this issue with other treatments such as sodium dichloro-s-triazinetrione (Jeong et al., 2016). Overall, if not applied correctly (in terms of dose, intensity, and duration), irradiation can adversely affect fruit quality parameters, stimulate phytotoxicities, and even impact human health. Combining irradiation treatment with other environmentally friendly techniques would help to minimize detrimental effects and increase efficacy.

Cold storage and storage in controlled or modified atmospheres are complementary tools that provide fungistatic activity by inhibiting or delaying the growth and development of pathogens. They also help reduce host metabolic activity, delay senescence, and maintain fruit resistance to fungal infection (Usall et al., 2016).

\section{OUTLOOK AND PROSPECTS}

Green and blue mold disease in citrus poses a major threat worldwide. The conventional disease management approaches involving synthetic fungicides are increasingly being questioned because of their potential deleterious impacts on human and environmental health, and the growing problem of fungi developing resistance to the synthetic fungicides. Non-toxic alternatives to synthetic fungicides include biological control, bio-fungicides, plant extracts and essential oils, chitosan, salts, hot water treatments and UV-radiation, and synthetic elicitors (Janisiewicz and Korsten, 2002; Droby et al., 2009). Although producers and consumers accept these new approaches, limited research has investigated the effectiveness of these methods on large-scale production. Not much is known about mechanisms of action of these alternative control approaches against green and blue mold disease, while the pathogen continues to cause huge economic losses. To manage these diseases, researchers might explore the molecular mechanisms of plant/fruit-pathogen interactions, including pathogenicity and plant resistance. Identification and functional analysis of citrus genes that regulate citrus fruit via transgenesis or genome editing may lead to the development of novel and durable control strategies against $P$. digitatum and $P$. italicum. Recent advances in the study of disease resistance in citrus are made possible, thanks to the availability of complete genome sequence of citrus, optimization of genetic transformation systems, and establishment of CRISPR/Cas9 gene-editing approaches. Thus, identification of resistant genes and developing resistant citrus varieties via genome editing might provide a promising pathway to control $P$. digitatum and P. italicum pathogens.

\section{AUTHOR CONTRIBUTIONS}

UB conceptualized the review, wrote the original draft, investigated, revised, and edited the draft manuscript.

\section{ACKNOWLEDGMENTS}

I sincerely thank Chandra Dhakal and Genevieve Guzman for their comments and English language editing. The author also thank the editor, Zhongwei Zou, and two referees for their comments and suggestions.

\section{REFERENCES}

Abbey, J. A., Percival, D., Abbey, L., Asiedu, S. K., Prithiviraj, B., and Schilder, A. (2019). Biofungicides as alternative to synthetic fungicide control of grey

mould (Botrytis cinerea)-prospects and challenges. Biocontrol Sci. Technol. 29, 207-228. doi: 10.1080/09583157.2018.1548574

Abraham, A. O., Laing, M. D., and Bower, J. P. (2010). Isolation and in vivo screening of yeast and Bacillus antagonists for the control 
of Penicillium digitatum of citrus fruit. Biol. Control 53, 32-38. doi: 10.1016/j.biocontrol.2009.12.009

Afek, U., Orenstein, J., Carmeli, S., Rodov, V., and Joseph, M. B. (1999). Umbelliferone, a phytoalexin associated with resistance of immature Marsh grapefruit to Penicillium digitatum. Phytochemistry 50, 1129-1132. doi: 10.1016/S0031-9422(98)00671-2

Aghdam, M. S., Luo, Z., Aminian-Dehkordi, R., Jannatizadeh, A., Farmani, B., Younessi-Hamzekhanlu, M., et al. (2020). Exogenous $\beta$-aminobutyric acid application attenuates Aspergillus decay, minimizes aflatoxin B1 accumulation, and maintains nutritional quality in fresh-in-hull pistachio kernels. J. Sci. Food Agric. 100, 2130-2135. doi: 10.1002/jsfa.10236

Agnioni, A., Cabras, P., Dhallewin, G., Pirisi, F. M., Reniero, F., and Schirra, M. (1998). Synthesis and inhibitory activity of 7-geranoxy coumarin against Penicillium species in citrus fruits. Phytochemistry 47, 1521-1525. doi: 10.1016/S0031-9422(97)00771-1

Ahmed, D. M., El-Shami, S. M., and El-Mallah, M. H. (2007). Jojoba oil as a novel coating for exported Valencia orange fruit. Part 1. The use of trans (isomerized) jojoba oil. Am. Eurasian. J. Agric. Environ. Sci. 2, 173-181.

Aloui, H., Licciardello, F., Khwaldia, K., Hamdi, M., and Restuccia, C. (2015). Physical properties and antifungal activity of bioactive films containing Wickerhamomyces anomalus killer yeast and their application for preservation of oranges and control of postharvest green mold caused by Penicillium digitatum. Int. J. Food Microbiol. 200, 22-30. doi: 10.1016/j.ijfoodmicro.2015.01.015

Al-Snafi, A. E. (2016). Nutritional value and pharmacological importance of citrus species grown in Iraq. IOSR J. Pharm. 6, 76-108. doi: 10.9790/3013-0680176108

Ameziane, N., Boubaker, H., Boudyach, H., Msanda, F., Jilal, A., and Benaoumar, A. A. (2007). Antifungal activity of Moroccan plants against citrus fruit pathogens. Agron. Sustain. Dev. 27, 273-277. doi: 10.1051/agro:2007022

Ariza, M. R., Larsen, T. O., Petersen, B. O., Duus, J. Ø., and Barrero, A. F. (2002). Penicillium digitatum metabolites on synthetic media and citrus fruits. J. Agric. Food Chem. 50, 6361-6365. doi: 10.1021/jf020398d

Arras, G. (1996). Mode of action of an isolate of Candida famata in biological control of Penicillium digitatum in orange fruits. Postharvest Biol. Technol. 8, 191-198. doi: 10.1016/0925-5214(95)00071-2

Arras, G., Scherm, B., and Migheli, Q. (2002). Improving biocontrol activity of Pichia guillermondii against post-harvest decay of oranges in commercial packing-houses by reduced concentrations of fungicides. Biocontrol Sci. Technol. 12, 547-553. doi: 10.1080/0958315021000016216

Arras, G., and Usai, M. (2001). Fungitoxic activity of 12 essential oils against four postharvest citrus pathogens: chemical analysis of Thymus capitatus oil and its effect in subatmospheric pressure conditions. J. Food Prot. 64, 1025-1029. doi: 10.4315/0362-028X-64.7.1025

Askarne, L., Boubaker, H., Boudyach, E. H., and Aoumar, A. A. B. (2013). Use of food additives to control postharvest citrus blue mold disease. Atlas J. Biol. 2, 147-153. doi: 10.5147/ajb.v2i3.25

Askarne, L., Talibi, I., Boubaker, H., Boudyach, E. H., Msanda, F., Saadi, B., et al. (2012). In vitro and in vivo antifungal activity of several Moroccan plants against Penicillium italicum, the causal agent of citrus blue mold. Crop Prot. 40, 53-58. doi: 10.1016/j.cropro.2012.04.023

Askarne, L., Talibi, I., Serghini, M. A., Boubaker, H., Msanda, F., Aoumar, A. A. B., and Boudyach, E. H. (2011). Antifungal activity of Moroccan plants against Penicillium italicum, the causal agent of blue mold of citrus. IOBC/wprs Bull. 62, 51-54.

Baccelli, I., Glauser, G., and Mauch-Mani, B. (2017). The accumulation of $\beta$ aminobutyric acid is controlled by the plant's immune system. Planta 246, 791-796. doi: 10.1007/s00425-017-2751-3

Bakkali, F., Averbeck, S., Averbeck, D., and Idaomar, M. (2008). Biological effects of essential oils-a review. Food Chem. Toxicol. 46, 446-475. doi: 10.1016/j.fct.2007.09.106

Ballester, A. R., and Lafuente, M. T. (2017). LED blue light-induced changes in phenolics and ethylene in citrus fruit: implication in elicited resistance against Penicillium digitatum infection. Food Chem. 218, 575-583. doi: 10.1016/j.foodchem.2016.09.089

Bar-Shimon, M., Yehuda, H., Cohen, L., Weiss, B., Kobeshnikov, A., Daus, A., et al. (2004). Characterization of extracellular lytic enzymes produced by the yeast biocontrol agent Candida oleophila. Curr. Genet. 45, 140-148. doi: $10.1007 /$ s00294-003-0471-7
Benavente-Garcia, O., and Castillo, J. (2008). Update on uses and properties of citrus flavonoids: new findings in anticancer, cardiovascular, and anti-inflammatory activity. J. Agric. Food Chem. 56, 6185-6205. doi: $10.1021 /$ jf8006568

Benhamou, N. (2004). Potential of the mycoparasite, Verticillium lecanii, to protect citrus fruit against Penicillium digitatum, the causal agent of green mold: a comparison with the effect of chitosan. Phytopathology 94, 693-705. doi: 10.1094/PHYTO.2004.94.7.693

Benhamou, N., and Brodeur, J. (2001). Pre-inoculation of Ri T-DNA transformed cucumber roots with the mycoparasite, Verticillium lecanii, induces host defense reactions against Pythium ultimum infection. Physiol. Mol. Plant Pathol. 58, 133-146. doi: 10.1006/pmpp.2001.0322

Ben-Yehoshua, S., and Porat, R. (2005). "Heat treatments to reduce decay," in Environmentally Friendly Technologies of Agricultural Produce Quality, ed S. B. Yeoshua (Boca Raton, FL: Taylor \& Francis Group), 11-42. doi: $10.1201 / 9780203500361$

Bodart, J. F., Béchard, D., Bertout, M., Rousseau, A., Gannon, J., Vilain, J. P., and Flament, S. (1999). Inhibition of protein tyrosine phosphatases blocks calciuminduced activation of metaphase II-arrested oocytes of Xenopus laevis. FEBS Lett. 457, 175-178. doi: 10.1016/S0014-5793(99)00986-2

Boubaker, H., Karim, H., El Hamdaoui, A., Msanda, F., Leach, D., Bombarda, I., et al. (2016). Chemical characterization and antifungal activities of four Thymus species essential oils against postharvest fungal pathogens of citrus. Ind. Crops Prod. 86, 95-101. doi: 10.1016/j.indcrop.2016. 03.036

Brown, G. E., and Eckert, J. W. (2000a). "Blue mold," in Compendium of Citrus Diseases, 2nd Edn, eds L. W. Timmer, S. M. Garnsey, and J. H. Graham (St. Paul, MN: American Phytopathological Society), 41.

Brown, G. E., and Eckert, J. W. (2000b). "Green mold," in Compendium of Citrus Diseases, 2nd Edn, eds L. W. Timmer, S. M. Garnsey, and J. H. Graham (St. Paul, MN: American Phytopathological Society), 41-42.

Cao, J., Zeng, K., and Jiang, W. (2006). Enhancement of postharvest disease resistance in Ya Li pear (Pyrus bretschneideri) fruit by salicylic acid sprays on the trees during fruit growth. Eur. J. Plant Pathol. 114, 363-370. doi: 10.1007/s10658-005-5401-8

Cerioni, L., Sepulveda, M., Rubio-Ames, Z., Volentini, S. I., RodríguezMontelongo, L., Smilanick, J. L., et al. (2013). Control of lemon postharvest diseases by low-toxicity salts combined with hydrogen peroxide and heat. Postharvest Biol. Technol. 83, 17-21. doi: 10.1016/j.postharvbio.2013. 03.002

Cháfer, M., Sánchez-González, L., González-Martínez, C., and Chiralt, A. (2012). Fungal decay and shelf life of oranges coated with chitosan and bergamot, thyme, and tea tree essential oils. J. Food Sci. 77, E182-E187. doi: $10.1111 /$ j.1750-3841.2012.02827.x

Chalutz, E., and Wilson, C. L. (1990). Postharvest biocontrol of green and blue mold and sour rot of citrus fruit by Debaryomyces hansenii. Plant Dis. 74, 134-137. doi: 10.1094/PD-74-0134

Che, J., Chen, X., Ouyang, Q., and Tao, N. (2020). p-Anisaldehyde exerts its antifungal activity against Penicillium digitatum and Penicillium italicum by disrupting the cell wall integrity and membrane permeability. J. Microbiol. Biotechnol. 30, 878-884. doi: 10.4014/jmb.1911.11032

Chen, C., Cai, N., Chen, J., and Wan, C. (2019). Clove essential oil as an alternative approach to control postharvest blue mold caused by Penicillium italicum in citrus fruit. Biomolecules 9:197. doi: 10.3390/biom9050197

Chen, C., Cai, N., Chen, J., and Wan, C. (2020a). UHPLC-Q-TOF/MSbased metabolomics approach reveals the antifungal potential of pinocembroside against citrus green mold phytopathogen. Plants 9:17. doi: 10.3390/plants9010017

Chen, C., Chen, J., and Wan, C. (2020b). Pinocembrin-7-glucoside (P7G) reduced postharvest blue mold of navel orange by suppressing Penicillium italicum growth. Microorganisms 8:536. doi: 10.3390/microorganisms8040536

Chen, C., Wan, C., Guo, J., and Chen, J. (2020c). Paenibacillus brasilensis YS-1: a potential biocontrol agent to retard Xinyu tangerine senescence. Agriculture 10:330. doi: 10.3390/agriculture 10080330

Chen, C., Wan, C., Peng, X., and Chen, J. (2020d). A flavonone pinocembroside inhibits Penicillium italicum growth and blue mold development in 'Newhall' navel oranges by targeting membrane damage mechanism. Pestic. Biochem. Physiol. 165:104505. doi: 10.1016/j.pestbp.2019.11.025 
Chen, D., Forster, H., and Adaskaveg, J. (2020e). Natamycin, a biofungicide for managing major postharvest fruit decays of citrus. Plant Dis. 105, 1408-1414. doi: 10.1094/PDIS-08-20-1650-RE

Chen, O., Deng, L., Ruan, C., Yi, L., and Zeng, K. (2021). Pichia galeiformis induces resistance in postharvest citrus by activating the phenylpropanoid biosynthesis pathway. J. Agric. Food Chem. 69, 2619-2631. doi: 10.1021/acs.jafc.0c06283

Chen, O., Yi, L., Deng, L., Ruan, C., and Zeng, K. (2020f). Screening antagonistic yeasts against citrus green mold and the possible biocontrol mechanisms of Pichia galeiformis (BAF03). J. Sci. Food Agric. 100, 3812-3821. doi: $10.1002 /$ jsfa. 10407

Chen, P., Peng, Y., Chung, W., Chung, K., Huang, H., and Huang, J. (2016). Inhibition of Penicillium digitatum and citrus green mold by volatile compounds produced by Enterobacter cloacae. J. Plant Pathol. Microbiol. 7:1000339. doi: 10.4172/2157-7471.1000339

Cheng, L., Nie, X., Jiang, C., and Li, S. (2019). The combined use of the antagonistic yeast Hanseniaspora uvarum with $\beta$-aminobutyric acid for the management of postharvest diseases of kiwifruit. Biol. Control 137:104019. doi: 10.1016/j.biocontrol.2019.104019

Cheong, J. J., and Do Choi, Y. (2003). Methyl jasmonate as a vital substance in plants. Trends Genet. 19, 409-413. doi: 10.1016/S0168-9525(03)00138-0

Cia, P., Pascholati, S. F., Benato, E. A., Camili, E. C., and Santos, C. A. (2007). Effects of gamma and UV-C irradiation on the postharvest control of papaya anthracnose. Postharvest Biol. Technol. 43, 366-373. doi: 10.1016/j.postharvbio.2006.10.004

Cohen, Y. R. (2002). $\beta$-aminobutyric acid-induced resistance against plant pathogens. Plant Dis. 86, 448-457. doi: 10.1094/PDIS.2002.86.5.448

Comitini, F., Mannazzu, I., and Ciani, M. (2009). Tetrapisispora phaffii killer toxin is a highly specific $\beta$-glucanase that disrupts the integrity of the yeast cell wall. Microb. Cell Fact. 8:55. doi: 10.1186/1475-2859-8-55

Conrath, U., Beckers, G. J., Langenbach, C. J., and Jaskiewicz, M. R. (2015). Priming for enhanced defense. Annu. Rev. Phytopathol. 53, 97-119. doi: 10.1146/annurev-phyto-080614-120132

Costa, J. H., Bazioli, J. M., Barbosa, L. D., dos Santos Júnior, P. L. T., Reis, F. C., Klimeck, T., et al. (2021). Phytotoxic tryptoquialanines produced in vivo by Penicillium digitatum are exported in extracellular vesicles. MBio 12:e03393-20. doi: $10.1128 / \mathrm{mBio} .03393-20$

Couey, H. M. (1989). Heat treatment for control of postharvest diseases and insect pests of fruits. HortScience 24, 198-202.

Cowan, M. M. (1999). Plant products as antimicrobial agents. Clin. Microbiol. Rev. 12, 564-582. doi: 10.1128/CMR.12.4.564

da Cunha, T., Ferraz, L. P., de Sousa-Júnior, G. D. S., and Kupper, K. C. (2020). The action of yeast strains as biocontrol agents against Penicillium digitatum in Lima sweet oranges. Citrus Res. Technol. 41:e1054. doi: 10.4322/crt.18819

da Cunha, T., Ferraz, L. P., Wehr, P. P., and Kupper, K. C. (2018). Antifungal activity and action mechanisms of yeasts isolates from citrus against Penicillium italicum. Int. J. Food Microbiol. 276, 20-27. doi: 10.1016/j.ijfoodmicro.2018.03.019

Daferera, D. J., Ziogas, B. N., and Polissiou, M. G. (2000). GC-MS analysis of essential oils from some Greek aromatic plants and their fungitoxicity on Penicillium digitatum. J. Agric. Food Chem. 48, 2576-2581. doi: $10.1021 /$ jf990835x

D’Aquino, S., Fadda, A., Barberis, A., Palma, A., Angioni, A., and Schirra, M. (2013). Combined effects of potassium sorbate, hot water and thiabendazole against green mould of citrus fruit and residue levels. Food Chem. 141, 858-864. doi: 10.1016/j.foodchem.2013.03.083

De Corato, U., Maccioni, O., Trupo, M., and Di Sanzo, G. (2010). Use of essential oil of Laurus nobilis obtained by means of a supercritical carbon dioxide technique against post-harvest spoilage fungi. Crop Prot. 29, 142-147. doi: 10.1016/j.cropro.2009.10.012

De Rodríguez, D. J., García, R. R., Castillo, F. H., González, C. A., Galindo, A. S., Quintanilla, J. V., and Zuccolotto, L. M. (2011). In vitro antifungal activity of extracts of Mexican Chihuahuan Desert plants against postharvest fruit fungi. Ind. Crops Prod. 34, 960-966. doi: 10.1016/j.indcrop.2011. 03.001

de Vilhena Araújo, É., Vendramini, P. H., Costa, J. H., Eberlin, M. N., Montagner, C. C., and Fill, T. P. (2019). Determination of tryptoquialanines A and C produced by Penicillium digitatum in oranges: are we safe? Food Chem. 301:125285. doi: 10.1016/j.foodchem.2019.125285
Del Río, J. A., Arcas, M. C., Benavente-García, O., and Ortuño, A. (1998). Citrus polymethoxylated flavones can confer resistance against Phytophthora citrophthora, Penicillium digitatum, and Geotrichum species. J. Agric. Food Chem. 46, 4423-4428. doi: 10.1021/jf980229m

Deliopoulos, T., Kettlewell, P. S., and Hare, M. C. (2010). Fungal disease suppression by inorganic salts: a review. Crop Prot. 29, 1059-1075. doi: $10.1016 /$ j.cropro.2010.05.011

Dennis, C., and Webster, J. (1971). Antagonistic properties of species-groups of Trichoderma: II. Production of volatile antibiotics. Trans. Br. Mycol. Soc. 57, 25-39. doi: 10.1016/S0007-1536(71)80077-3

D'Hallewin, G., Schirra, M., Pala, M., and Ben-Yehoshua, S. (2000). Ultraviolet C irradiation at $0.5 \mathrm{~kJ} . \mathrm{m}(-)(2)$ reduces decay without causing damage or affecting postharvest quality of star ruby grapefruit (C. paradisi Macf.). J. Agric. Food Chem. 48, 4571-4575. doi: 10.1021/jf000559i

Dixit, S. N., Chandra, H., Tiwari, R., and Dixit, V. (1995). Development of a botanical fungicide against blue mould of mandarins. J. Stored Prod. Res. 31, 165-172. doi: 10.1016/0022-474X(94)00041-Q

Droby, S., and Chalutez, E. (1999). Biological control of postharvest decay in citrus fruit. Advances in postharvest diseases and disorders control of citrus fruit. Research Signpost, Trivandrum, India. Eur. J. Plant Pathol. 123, 37-45.

Droby, S., Chalutz, E., Horev, B., Cohen, L., Gaba, V., Wilson, C. L., and Wisniewski, M. (1993). Factors affecting UV-induced resistance in grapefruit against the green mould decay caused by Penicillium digitatum. Plant Pathol. 42, 418-424. doi: 10.1111/j.1365-3059.1993.tb01520.x

Droby, S., Chalutz, E., Wilson, C. L., and Wisniewski, M. (1989). Characterization of the biocontrol activity of Debaryomyces hansenii in the control of Penicillium digitatum on grapefruit. Can. J. Microbiol. 35, 794-800. doi: 10.1139/m89-132

Droby, S., Cohen, L., Daus, A., Weiss, B., Horev, B., Chalutz, E., et al. (1998). Commercial testing of Aspire: a yeast preparation for the biological control of postharvest decay of citrus. Biol. Control 12, 97-101. doi: 10.1006/bcon.1998.0615

Droby, S., Eick, A., Macarisin, D., Cohen, L., Rafael, G., Stange, R., et al. (2008). Role of citrus volatiles in host recognition, germination and growth of Penicillium digitatum and Penicillium italicum. Postharvest Biol. Technol. 49, 386-396. doi: 10.1016/j.postharvbio.2008.01.016

Droby, S., Vinokur, V., Weiss, B., Cohen, L., Daus, A., Goldschmidt, E. E., and Porat, R. (2002). Induction of resistance to Penicillium digitatum in grapefruit by the yeast biocontrol agent Candida oleophila. Phytopathology 92, 393-399. doi: 10.1094/PHYTO.2002.92.4.393

Droby, S., Wisniewski, M., Macarisin, D., and Wilson, C. (2009). Twenty years of postharvest biocontrol research: is it time for a new paradigm? Postharvest Biol. Technol. 52, 137-145. doi: 10.1016/j.postharvbio.2008.11.009

Droby, S., Wisniewski, M. E., Cohen, L., Weiss, B., Touitou, D., Eilam, Y., and Chalutz, E. (1997). Influence of $\mathrm{CaCl}_{2}$ on Penicillium digitatum, grapefruit peel tissue, and biocontrol activity of Pichia guilliermondii. Phytopathology 87, 310-315. doi: 10.1094/PHYTO.1997.87.3.310

Du Plooy, W., Regnier, T., and Combrinck, S. (2009). Essential oil amended coatings as alternatives to synthetic fungicides in citrus postharvest management. Postharvest Biol. Technol. 53, 117-122. doi: 10.1016/j.postharvbio.2009.04.005

Duan, X., Jing, G., Fan, F., and Tao, N. (2016). Control of postharvest green and blue molds of citrus fruit by application of sodium dehydroacetate. Postharvest Biol. Technol. 113, 17-19. doi: 10.1016/j.postharvbio.2015.10.015

El Guilli, M., Hamza, A., Clément, C., Ibriz, M., and Ait Barka, E. (2016). Effectiveness of postharvest treatment with chitosan to control citrus green mold. Agriculture 6:12. doi: 10.3390/agriculture6020012

El Guilli, M., Jijakli, M. H., and Lahlali, R. (2020). Pilot testing of two biofungicide formulations for the control of citrus blue and green mold in two Moroccan packinghouses. Moroccan J. Agric. Sci. 1, 215-220.

El-Esawi, M., Arthaut, L. D., Jourdan, N., d'Harlingue, A., Link, J., Martino, C. F., and Ahmad, M. (2017). Blue-light induced biosynthesis of ROS contributes to the signaling mechanism of Arabidopsis cryptochrome. Sci. Rep. 7:13875. doi: 10.1038/s41598-017-13832-z

El-Ghaouth, A., Smilanick, J. L., and Wilson, C. L. (2000). Enhancement of the performance of Candida saitoana by the addition of glycolchitosan for the control of postharvest decay of apple and citrus fruit. Postharvest Biol. Technol. 19, 103-110. doi: 10.1016/S0925-5214(00)00 076-4 
El-Mohamedy, R. S., El-Gamal, N. G., and Bakeer, A. R. T. (2015). Application of chitosan and essential oils as alternatives fungicides to control green and blue moulds of citrus fruits. Int. J. Curr. Microbiol. Appl. Sci 4, 629-643.

El-Mougy, N. S., El-Gamal, N. G., and Abd-El-Kareem, F. (2008). Use of organic acids and salts to control postharvest diseases of lemon fruits in Egypt. Archiv. Phytopathol. Plant Protect. 41, 467-476. doi: 10.1080/03235400600813532

Eloff, J. N., and Mahlo, S. N. (2011). Breonadia salicina (Rubiaceae) extracts are as effective as a commercial fungicide in post-harvest protection of oranges against Penicillium infections. Planta Med. 77:PM219. doi: 10.1055/s-0031-1282977

Elsherbiny, E. A., Dawood, D. H., and Safwat, N. A. (2021). Antifungal action and induction of resistance by $\beta$-aminobutyric acid against Penicillium digitatum to control green mold in orange fruit. Pestic. Biochem. Physiol. 171:104721. doi: 10.1016/j.pestbp.2020.104721

Exarchou, V., Kanetis, L., Charalambous, Z., Apers, S., Pieters, L., Gekas, V., and Goulas, V. (2015). HPLC-SPE-NMR characterization of major metabolites in Salvia fruticosa Mill. Extract with antifungal potential: relevance of carnosic acid, carnosol, and hispidulin. J. Agric. Food Chem. 63, 457-463. doi: 10.1021/jf5050734

Ezra, D., Hess, W. M., and Strobel, G. A. (2004). New endophytic isolates of Muscodor albus, a volatile-antibiotic-producing fungus. Microbiology 150, 4023-4031. doi: 10.1099/mic.0.27334-0

Fallanaj, F., Ippolito, A., Ligorio, A., Garganese, F., Zavanella, C., and Sanzani, S. M. (2016). Electrolyzed sodium bicarbonate inhibits Penicillium digitatum and induces defence responses against green mould in citrus fruit. Postharvest Biol. Technol. 115, 18-29. doi: 10.1016/j.postharvbio.2015.12.009

Fan, F., Tao, N., Jia, L., and He, X. (2014). Use of citral incorporated in postharvest wax of citrus fruit as a botanical fungicide against Penicillium digitatum. Postharvest Biol. Technol. 90, 52-55. doi: 10.1016/j.postharvbio.2013.12.005

Fatemi, S., Jafarpour, M., and Eghbalsaied, S. (2012). Study of the effect of Thymus vulgaris and hot water treatment on storage life of orange (Citrus sinensis CV. Valencia). J. Med. Plants Res. 6, 968-971. doi: 10.5897/JMPR11.475

Ferraz, L. P., da Cunha, T., da Silva, A. C., and Kupper, K. C. (2016). Biocontrol ability and putative mode of action of yeasts against Geotrichum citri-aurantii in citrus fruit. Microbiol. Res. 188, 72-79. doi: 10.1016/j.micres.2016.04.012

Fisher, K., and Phillips, C. (2008). Potential antimicrobial uses of essential oils in food: is citrus the answer? Trends Food Sci. Technol. 19, 156-164. doi: 10.1016/j.tifs.2007.11.006

Fravel, D. R., and Larkin, R. P. (1996). Availability and application of biocontrol products. Biol. Cult. Tests Control Plant Dis. 11, 1-7.

Fu, L. H., Hu, K. D., Hu, L. Y., Li, Y. H., Hu, L. B., Yan, H., et al. (2014). An antifungal role of hydrogen sulfide on the postharvest pathogens Aspergillus niger and Penicillium italicum. PLoS ONE 9:e104206. doi: 10.1371/journal.pone.0104206

Galed, G., Fernández-Valle, M. E., Martinez, A., and Heras, A. (2004). Application of MRI to monitor the process of ripening and decay in citrus treated with chitosan solutions. Magn. Reson. Imaging 22, 127-137. doi: 10.1016/j.mri.2003.05.006

Gamagae, S. U., Sivakumar, D., and Wijesundera, R. L. C. (2004). Evaluation of post-harvest application of sodium bicarbonate-incorporated wax formulation and Candida oleophila for the control of anthracnose of papaya. Crop Prot. 23, 575-579. doi: 10.1016/j.cropro.2003.11.003

García, J. F., Olmo, M., and García, J. M. (2016). Decay incidence and quality of different citrus varieties after postharvest heat treatment at laboratory and industrial scale. Postharvest Biol. Technol. 118, 96-102. doi: 10.1016/j.postharvbio.2016.03.019

Gatto, M. A., Ippolito, A., Linsalata, V., Cascarano, N. A., Nigro, F., Vanadia, S., and Di Venere, D. (2011). Activity of extracts from wild edible herbs against postharvest fungal diseases of fruit and vegetables. Postharvest Biol. Technol. 61, 72-82. doi: 10.1016/j.postharvbio.2011.02.005

Geng, P., Chen, S., Hu, M., Rizwan-ul-Haq, M., Lai, K., Qu, F., and Zhang, Y. (2011). Combination of Kluyveromyces marxianus and sodium bicarbonate for controlling green mold of citrus fruit. Int. J. Food Microbiol. 151, 190-194. doi: 10.1016/j.ijfoodmicro.2011.08.023

Guerreiro, D., Madureira, J., Silva, T., Melo, R., Santos, P. M., Ferreira, A., et al. (2016). Post-harvest treatment of cherry tomatoes by gamma radiation: microbial and physicochemical parameters evaluation. Innovat. Food Sci. Emerg. Technol. 36, 1-342. doi: 10.1016/j.ifset.2016.05.008
Gündüz, G. T., and Pazir, F. (2013). Inactivation of Penicillium digitatum and Penicillium italicum under in vitro and in vivo conditions by using UV-C light. J. Food Prot. 76, 1761-1766. doi: 10.4315/0362-028X.JFP-12-511

Guo, J., Fang, W., Lu, H., Zhu, R., Lu, L., Zheng, X., and Yu, T. (2014). Inhibition of green mold disease in mandarins by preventive applications of methyl jasmonate and antagonistic yeast Cryptococcus laurentii. Postharvest Biol. Technol. 88, 72-78. doi: 10.1016/j.postharvbio.2013.09.008

Guolin, L., Meng, F., Wei, X., and Lin, M. (2019). Postharvest dipping treatment with BABA induced resistance against rot caused by Gilbertella persicaria in red pitaya fruit. Sci. Hortic. 257:108713. doi: 10.1016/j.scienta.2019. 108713

Hafdani, F. N., and Sadeghinia, N. (2011). A review on application of chitosan as a natural antimicrobial. World Acad. Sci. Eng. Technol. 50, 252-256.

Hall, D. J. (1988). "Comparative activity of selected food preservatives as citrus postharvest fungicides," in Proceedings of the Annual Meeting of the Florida State Horticulture Society (USA) (Orlando, FL).

Hall, D. J., and Fernandez, Y. J. (2004). "In vitro evaluation of selected essential oils as fungicides against Penicillium digitatum sacc," in Proceedings of the Florida State Horticultural Society, Vol. 117 (Mascotte, FL), 377-379.

Han, Q., Zhao, H., Cheng, Y., Yao, J., Huang, L., and Kang, Z. (2013). A cytological study on infection of citrus fruits by Penicillium digitatum. Mycosystema 32, 967-977.

Hao, W., Li, H., Hu, M., Yang, L., and Rizwan-ul-Haq, M. (2011). Integrated control of citrus green and blue mold and sour rot by Bacillus amyloliquefaciens in combination with tea saponin. Postharvest Biol. Technol. 59, 316-323. doi: 10.1016/j.postharvbio.2010.10.002

Hao, W., Zhong, G., Hu, M., Luo, J., Weng, Q., and Rizwan-ul-Haq, M. (2010). Control of citrus postharvest green and blue mold and sour rot by tea saponin combined with imazalil and prochloraz. Postharvest Biol. Technol. 56, 39-43. doi: 10.1016/j.postharvbio.2009.10.003

Hendel, N., Larous, L., and Belbey, L. (2016). Antioxidant activity of rosemary (Rosmarinus officinalis L.) and its in vitro inhibitory effect on Penicillium digitatum. Int. Food Res. J. 23, 1725-1732.

Hernández-Montiel, L. G., Ochoa, J. L., Troyo-Diéguez, E., and Larralde-Corona, C. P. (2010). Biocontrol of postharvest blue mold (Penicillium italicum Wehmer) on Mexican lime by marine and citrus Debaryomyces hansenii isolates. Postharvest Biol. Technol. 56, 181-187. doi: 10.1016/j.postharvbio.2009.12.010

Holmes, G. J., and Eckert, J. W. (1999). Sensitivity of Penicillium digitatum and Penicillium italicum to postharvest citrus fungicides in California. Phytopathology 89, 716-721. doi: 10.1094/PHYTO.1999.89.9.716

Holopainen, J. K., Heijari, J., Nerg, A. M., Vuorinen, M., and Kainulainen, P. (2009). Potential for the use of exogenous chemical elicitors in disease and insect pest management of conifer seedling production. Open For. Sci. J. 2, 17-24. doi: 10.2174/1874398600902010017

Huang, Y., Deverall, B. J., and Morris, S. C. (1995). Postharvest control of green mould on oranges by a strain of Pseudomonas glathei and enhancement of its biocontrol by heat treatment. Postharvest Biol. Technol. 5, 129-137. doi: 10.1016/0925-5214(94)00016-L

Hulot, J. F., and Hiller, N. (2021). Exploring the Benefits of Biocontrol for Sustainable Agriculture - A Literature Review on Biocontrol in Light of the European Green Deal. Brussels: Institute for European Environmental Policy.

Ippolito, A., and Nigro, F. (2000). Impact of preharvest application of biological control agents on postharvest diseases of fresh fruits and vegetables. Crop Prot. 19, 715-723. doi: 10.1016/S0261-2194(00)00095-8

Iqbal, Z., Iqbal, J., Abbas, I., and Kamran, M. (2017). Innovative strategies for ecofriendly management of citrus blue mold disease caused by Penicillium italicum Wehmer. J. Int. Sci. Publ. Agric. Food 5, 361-365.

Iqbal, Z., Singh, Z., Khangura, R., and Ahmad, S. (2012). Management of citrus blue and green moulds through application of organic elicitors. Austral. Plant Pathol. 41, 69-77. doi: 10.1007/s13313-011-0091-5

Janisiewicz, W. J., and Korsten, L. (2002). Biological control of postharvest diseases of fruits. Annu. Rev. Phytopathol. 40, 411-441. doi: 10.1146/annurev.phyto.40.120401.130158

Jeong, R. D., Chu, E. H., Lee, G. W., Cho, C., and Park, H. J. (2016). Inhibitory effect of gamma irradiation and its application for control of postharvest green mold decay of Satsuma mandarins. Int. J. Food Microbiol. 234, 1-8. doi: 10.1016/j.ijfoodmicro.2016.06.026 
Jhalegar, M. J., Sharma, R. R., and Singh, D. (2015). In vitro and in vivo activity of essential oils against major postharvest pathogens of Kinnow (Citrus nobilis $\times$ C. deliciosa) mandarin. J. Food Sci. Technol. 52, 2229-2237. doi: 10.1007/s13197-014-1281-2

Jing, J. Y., Zhang, H. Y., Xue, Y. B., and Zeng, K. F. (2020). Effects of INA on postharvest blue and green molds and anthracnose decay in citrus fruit. $J$. Integr. Agric. 19, 1396-1406. doi: 10.1016/S2095-3119(20)63169-0

Johann, S., Oliveira, V. L. D., Pizzolatti, M. G., Schripsema, J., Braz-Filho, R., Branco, A., and Smânia, A. Jr. (2007). Antimicrobial activity of wax and hexane extracts from Citrus spp. peels. Memórias do Instituto Oswaldo Cruz 102, 681-685. doi: 10.1590/S0074-02762007000600004

Joyce, D. C., Wearing, H., Coates, L., and Terry, L. (2001). Effects of phosphonate and salicylic acid treatments on anthracnose disease development and ripening of 'Kensington Pride' mango fruit. Aust. J. Exp. Agric. 41, 805-813. doi: 10.1071/EA99104

Kader, A. A. (2002). Postharvest Technology of Horticultural Crops, Vol. 3311. Davis, CA: University of California Agriculture and Natural Resources.

Kaewsuksaeng, S., Urano, Y., Aiamla-or, S., Shigyo, M., and Yamauchi, N. (2011). Effect of UV-B irradiation on chlorophyll-degrading enzyme activities and postharvest quality in stored lime (Citrus latifolia Tan.) fruit. Postharvest Biol. Technol. 61, 124-130. doi: 10.1016/j.postharvbio.2011.02.014

Kanan, G., and Al-Najar, R. (2009). In vitro and in vivo activity of selected plant crude extracts and fractions against Penicillium italicum. J. Plant Protect. Res. 49, 341-352. doi: 10.2478/v10045-009-0054-9

Kanetis, L., Förster, H., and Adaskaveg, J. E. (2007). Comparative efficacy of the new postharvest fungicides azoxystrobin, fludioxonil, and pyrimethanil for managing citrus green mold. Plant Dis. 91, 1502-1511. doi: 10.1094/PDIS-91-11-1502

Kavanagh, J. A., and Wood, R. K. S. (1971). Green mould of oranges caused by Penicillium digitatum Sacc.; effect of additives on spore germination and infection. Ann. Appl. Biol. 67, 35-44. doi: 10.1111/j.1744-7348.1971.tb02906.x

Khakimov, A. A., Omonlikov, A. U., and Utaganov, S. B. U. (2020). Current status and prospects of the use of biofungicides against plant diseases. GSC Biol. Pharmac. Sci. 13, 119-126. doi: 10.30574/gscbps.2020.13.3.0403

Kim, J. J., Ben-Yehoshua, S., Shapiro, B., Henis, Y., and Carmeli, S. (1991). Accumulation of scoparone in heat-treated lemon fruit inoculated with Penicillium digitatum Sacc. Plant Physiol. 97, 880-885. doi: 10.1104/pp.97.3.880

Kim, P. I., and Chung, K. C. (2004). Production of an antifungal protein for control Colletotrichum lagenarium by Bacillus amyloliquefaciens MET0908. FEMS Microbiol. Lett. 234, 177-183. doi: 10.1016/j.femsle.2004.03.032

Kinay, P., Yildiz, F., Sen, F., Yildiz, M., and Karacali, I. (2005). Integration of pre- and postharvest treatments to minimize Penicillium decay of Satsuma mandarins. Postharvest Biol. Technol. 37, 31-36. doi: 10.1016/j.postharvbio.2005.02.008

Klieber, A., Scott, E., and Wuryatmo, E. (2002). Effect of method of application on antifungal efficacy of citral against postharvest spoilage fungi of citrus in culture. Austral. Plant Pathol. 31, 329-332. doi: 10.1071/AP0 2034

Koltz, E. A., dos Santos, I., Dallemole-Giaretta, R., Pazolini, K., Leite, C. D., and Steilmann, P. (2020). Combining Brassica sachets and extracts with thermotherapy against postharvest green mold of orange. Sci. Hortic. 268:109389. doi: 10.1016/j.scienta.2020.109389

Kouassi, K. H. S., Bajji, M., and Jijakli, H. (2012). The control of postharvest blue and green molds of citrus in relation with essential oil-wax formulations, adherence and viscosity. Postharvest Biol. Technol. 73, 122-128. doi: 10.1016/j.postharvbio.2012.06.008

Kupper, K. C., Cervantes, A. L. L., Klein, M. N., and Da Silva, A. C. (2013). Assessment of antagonistic micro-organisms Saccharomyces cerevisiae and Bacillus subtilis for controlling Penicillium digitatum. Rev. Bras. Frutic. 35, 425-436. doi: 10.1590/S0100-29452013000200011

Kurtzman, C. P., and Droby, S. (2001). Metschnikowia fructicola, a new ascosporic yeast with potential for biocontrol of postharvest fruit rots. Syst. Appl. Microbiol. 24, 395-399. doi: 10.1078/0723-2020-00045

Kyriacou, M. C. (2011). Influence of a post-harvest hot water treatment on the development of green mould [Penicillium digitatum (Pers.: Fr.) Sacc.] and on the quality of 'Mandora'fruit [Citrus reticulata Blanco Citrus sinensis (L.) Osbeck]. J. Hortic. Sci. Biotechnol. 86, 359-365. doi: $10.1080 / 14620316.2011 .11512774$
Ladaniya, M. S. (2008). "Commercial fresh citrus cultivars and producing countries," in Citrus Fruit: Biology, Technology and Evaluation, ed M. S. Ladaniya (San Diego, CA: Academic Press), 13-65. doi: 10.1016/B978-012374130-1.50004-8

Ladaniya, M. S. (2011). Physico-chemical, respiratory and fungicide residue changes in wax coated mandarin fruit stored at chilling temperature with intermittent warming. J. Food Sci. Technol. 48, 150-158. doi: 10.1007/s13197-010-0160-8

Lafuente, M. T., and Alférez, F. (2015). Effect of LED blue light on Penicillium digitatum and Penicillium italicum strains. Photochem. Photobiol. 91, 1412-1421. doi: 10.1111/php.12519

Lahlali, R., Hamadi, Y., Drider, R., Misson, C., El Guilli, M., and Jijakli, M. H. (2014). Control of citrus blue mold by the antagonist yeast Pichia guilliermondii Z1: compatibility with commercial fruit waxes and putative mechanisms of action. Food Control 45, 8-15. doi: 10.1016/j.foodcont.2014.04.014

Lai, K., Chen, S., Hu, M., Hu, Q., Geng, P., Weng, Q., and Jia, J. (2012). Control of postharvest green mold of citrus fruit by application of endophytic Paenibacillus polymyxa strain SG-6. Postharvest Biol. Technol. 69, 40-48. doi: 10.1016/j.postharvbio.2012.03.001

Lanciotti, R., Gianotti, A., Patrignani, F., Belletti, N., Guerzoni, M. E., and Gardini, F. (2004). Use of natural aroma compounds to improve shelf-life and safety of minimally processed fruits. Trends Food Sci. Technol. 15, 201-208. doi: $10.1016 /$ j.tifs.2003.10.004

Lanza, G., and Di Martino Aleppo, E. (1996). "Control of green mould of oranges and lemons by curing at high temperatures," in Proceedings of the International Society of Citriculture : VIII International Citrus Congress (Sun City Resort), 12-17.

Lanza, G., Di Martino Aleppo, E., and Strano, M. C. (2002). "Evaluation of alternative treatments to control green mold in citrus fruit," in XXVI International Horticultural Congress: Citrus and Other Subtropical and Tropical Fruit Crops: Issues, Advances and Opportunities, Vol. 632 (Toronto, ON), 343-349. doi: 10.17660/ActaHortic.2004.632.45

Leelasuphakul, W., Hemmanee, P., and Chuenchitt, S. (2008). Growth inhibitory properties of Bacillus subtilis strains and their metabolites against the green mold pathogen (Penicillium digitatum Sacc.) of citrus fruit. Postharvest Biol. Technol. 48, 113-121. doi: 10.1016/j.postharvbio.2007.09.024

Li, J., Li, H., Ji, S., Chen, T., Tian, S., and Qin, G. (2019). Enhancement of biocontrol efficacy of Cryptococcus laurentii by cinnamic acid against Penicillium italicum in citrus fruit. Postharvest Biol. Technol. 149, 42-49. doi: 10.1016/j.postharvbio.2018.11.018

Liao, H. L., Alferez, F., and Burns, J. K. (2013). Assessment of blue light treatments on citrus postharvest diseases. Postharvest Biol. Technol. 81, 81-88. doi: 10.1016/j.postharvbio.2013.02.019

Lin, Y., Fan, L., Xia, X., Wang, Z., Yin, Y., Cheng, Y., and Li, Z. (2019). Melatonin decreases resistance to postharvest green mold on citrus fruit by scavenging defense-related reactive oxygen species. Postharvest Biol. Technol. 153, 21-30. doi: 10.1016/j.postharvbio.2019.03.016

Liu, J., Sui, Y., Wisniewski, M., Droby, S., and Liu, Y. (2013). Utilization of antagonistic yeasts to manage postharvest fungal diseases of fruit. Int. J. Food Microbiol. 167, 153-160. doi: 10.1016/j.ijfoodmicro.2013.09.004

Liu, X., Fang, W., Liu, L., Yu, T., Lou, B., and Zheng, X. (2010). Biological control of postharvest sour rot of citrus by two antagonistic yeasts. Lett. Appl. Microbiol. 51, 30-35. doi: 10.1111/j.1472-765X.2010.02851.x

Liu, Y., Wang, W., Zhou, Y., Yao, S., Deng, L., and Zeng, K. (2017). Isolation, identification and in vitro screening of Chongqing orangery yeasts for the biocontrol of Penicillium digitatum on citrus fruit. Biol. Control 110, 18-24. doi: 10.1016/j.biocontrol.2017.04.002

Liu, Y., Yao, S., Deng, L., Ming, J., and Zeng, K. (2019). Different mechanisms of action of isolated epiphytic yeasts against Penicillium digitatum and Penicillium italicum on citrus fruit. Postharvest Biol. Technol. 152, 100-110. doi: 10.1016/j.postharvbio.2019. 03.002

Long, C. A., Deng, B. X., and Deng, X. X. (2007). Commercial testing of Kloeckera apiculata, isolate 34-9, for biological control of postharvest diseases of citrus fruit. Ann. Microbiol. 57, 203-207. doi: 10.1007/BF03175208

Louw, J. P., and Korsten, L. (2015). Pathogenicity and host susceptibility of Penicillium spp. on citrus. Plant Dis. 99, 21-30. doi: 10.1094/PDIS-02-14-0122-RE 
Lu, L., Ji, L., Qiao, L., Zhang, Y., Chen, M., Wang, C., et al. (2018). Combined treatment with Rhodosporidium paludigenum and ammonium molybdate for the management of green mold in satsuma mandarin (Citrus unshiu Marc.). Postharvest Biol. Technol. 140, 93-99. doi: 10.1016/j.postharvbio.2018.01.005

Luo, Y., Zeng, K., and Ming, J. (2012). Control of blue and green mold decay of citrus fruit by Pichia membranefaciens and induction of defense responses. Sci. Hortic. 135, 120-127. doi: 10.1016/j.scienta.2011.11.031

Maldonado, M. C., Orosco, C. E. F., Gordillo, M., and Navarro, A. R. (2010). In vivo and in vitro antagonism of Streptomyces sp. RO3 against Penicillium digitatum and Geotrichum candidum. Afr. J. Microbiol. Res. 4, 2451-2456.

Margosan, D. A., and Smilanick, J. L. (1998). Mortality of spores of Botrytis cinerea, Monilinia fructicola, Penicillium digitatum, and Rhizopus stolonifer after exposure to ozone under humid conditions. Phytopathology 88:S58.

Mari, M., and Guizzardi, M. (1998). The postharvest phase: emerging technologies for the control of fungal diseases. Phytoparasitica 26, 59-66. doi: 10.1007/BF02981267

Martínez-Blay, V., Taberner, V., Pérez-Gago, M. B., and Palou, L. (2020). Control of major citrus postharvest diseases by sulfur-containing food additives. Int. J. Food Microbiol. 330:108713. doi: 10.1016/j.ijfoodmicro.2020.108713

Matrose, N. A., Obikeze, K., Belay, Z. A., and Caleb, O. J. (2021). Plant extracts and other natural compounds as alternatives for postharvest management of fruit fungal pathogens: a review. Food Bioscience 41:100840. doi: 10.1016/j.fbio.2020.100840

Mekbib, S. B., Regnier, T. J., and Korsten, L. (2007). Control of Penicillium digitatum on citrus fruit using two plant extracts and study of their mode of action. Phytoparasitica 35, 264-276. doi: 10.1007/BF02981160

Mekbib, S. B., Regnier, T. J., Sivakumar, D., and Korsten, L. (2009). Evaluation of Ethiopian plant extracts, Acacia seyal and Withania somnifera, to control green mould and ensure quality maintenance of citrus (Citrus sinensis L.). Fruits 64, 285-294. doi: 10.1051/fruits/2009023

Meng, X., Han, J., Wang, Q., and Tian, S. (2009). Changes in physiology and quality of peach fruits treated by methyl jasmonate under low temperature stress. Food Chem. 114, 1028-1035. doi: 10.1016/j.foodchem.2008.09.109

Mercier, J., and Smilanick, J. L. (2005). Control of green mold and sour rot of stored lemon by biofumigation with Muscodor albus. Biol. Control 32, 401-407. doi: 10.1016/j.biocontrol.2004.12.002

Meziane, H., Gavriel, S., Ismailov, Z., Chet, I., Chernin, L., and Höfte, M. (2006). Control of green and blue mould on orange fruit by Serratia plymuthica strains IC14 and IC1270 and putative modes of action. Postharvest Biol. Technol. 39, 125-133. doi: 10.1016/j.postharvbio.2005.10.007

Montesinos-Herrero, C., Moscoso-Ramírez, P. A., and Palou, L. (2016). Evaluation of sodium benzoate and other food additives for the control of citrus postharvest green and blue molds. Postharvest Biol. Technol. 115, 72-80. doi: $10.1016 /$ j.postharvbio.2015.12.022

Montesinos-Herrero, C., and Palou, L. (2016). Synergism between potassium sorbate dips and brief exposure to high $\mathrm{CO}_{2}$ or $\mathrm{O}_{2}$ at curing temperature for the control of citrus postharvest green and blue molds. Crop Prot. 81, 43-46. doi: 10.1016/j.cropro.2015.12.005

Montesinos-Herrero, C., Smilanick, J. L., Tebbets, J. S., Walse, S., and Palou, L. (2011). Control of citrus postharvest decay by ammonia gas fumigation and its influence on the efficacy of the fungicide imazalil. Postharvest Biol. Technol. 59, 85-93. doi: 10.1016/j.postharvbio.2010.07.010

Moosa, A., Sahi, S. T., Khan, S. A., and Malik, A. U. (2019). Salicylic acid and jasmonic acid can suppress green and blue moulds of citrus fruit and induce the activity of polyphenol oxidase and peroxidase. Folia Hortic. 31, 195-204. doi: 10.2478/fhort-2019-0014

Moraes Bazioli, J., Belinato, J. R., Costa, J. H., Akiyama, D. Y., Pontes, J. G. D. M., Kupper, K. C., et al. (2019). Biological control of citrus postharvest phytopathogens. Toxins 11:460. doi: 10.3390/toxins11080460

Moretto, C., Cervantes, A. L. L., Batista Filho, A., and Kupper, K. C. (2014). Integrated control of green mold to reduce chemical treatment in post-harvest citrus fruits. Sci. Hortic. 165, 433-438. doi: 10.1016/j.scienta.2013.11.019

Moscoso-Ramírez, P. A., Montesinos-Herrero, C., and Palou, L. (2013). Control of citrus postharvest Penicillium molds with sodium ethylparaben. Crop Prot. 46, 44-51. doi: 10.1016/j.cropro.2012.12.007

Mukhopadhyay, N. K., Saha, A. K., Lovelace, J. K., Da silva, R., Sacks, D., 1., and Glew, R. H. (1988). Comparison of the protein kinase and acid phosphatase activities of five species of Leishmania. J. Protozool. 35, 601-607. doi: 10.1111/j.1550-7408.1988.tb04158.x

Musto, M., Potenza, G., and Francesco, C. (2014). Inhibition of Penicillium digitatum by a crude extract from Solanum nigrum leaves. BASE 18, 174-180.

Nafussi, B., Ben-Yehoshua, S., Rodov, V., Peretz, J., Ozer, B. K., and D'Hallewin, G. (2001). Mode of action of hot-water dip in reducing decay of lemon fruit. J. Agric. Food Chem. 49, 107-113. doi: 10.1021/jf000700n

Najmeh, S., Hosein, S. B. G., Sareh, S., and Bonjar, L. S. (2014). Biological control of citrus green mould, Penicillium digitatum, by antifungal activities of Streptomyces isolates from agricultural soils. Afr. J. Microbiol. Res. 8, 1501-1509. doi: 10.5897/AJMR2013.6289

Nantawanit, N., Chanchaichaovivat, A., Panijpan, B., and Ruenwongsa, P. (2010). Induction of defense response against Colletotrichum capsici in chili fruit by the yeast Pichia guilliermondii strain R13. Biol. Control 52, 145-152. doi: 10.1016/j.biocontrol.2009.10.011

Nicosia, M. G. L. D., Pangallo, S., Raphael, G., Romeo, F. V., Strano, M. C., Rapisarda, P., et al. (2016). Control of postharvest fungal rots on citrus fruit and sweet cherries using a pomegranate peel extract. Postharvest Biol. Technol. 114, 54-61. doi: 10.1016/j.postharvbio.2015.11.012

Nunes, C., Manso, T., and Lima-Costa, M. E. (2009). Postharvest biological control of citrus fruit. Tree For. Sci. Biotechnol. 3, 116-126.

Nunes, C., Usall, J., Manso, T., Torres, R., Olmo, M., and García, J. M. (2007). Effect of high temperature treatments on growth of Penicillium spp. and their development on 'Valencia'oranges. Food Sci. Technol. Int. 13, 63-68. doi: $10.1177 / 1082013207075601$

Obagwu, J., and Korsten, L. (2003). Control of citrus green and blue molds with garlic extracts. Eur. J. Plant Pathol. 109, 221-225. doi: 10.1023/A:1022839921289

Oufedjikh, H., Mahrouz, M., Amiot, M. J., and Lacroix, M. (2000). Effect of $\gamma$ irradiation on phenolic compounds and phenylalanine ammonia-lyase activity during storage in relation to peel injury from peel of Citrus clementina hort. Ex. tanaka. J. Agric. Food Chem. 48, 559-565. doi: 10.1021/jf9902402

Oyourou, J. N., Combrinck, S., Regnier, T., and Marston, A. (2013). Purification, stability and antifungal activity of verbascoside from Lippia javanica and Lantana camara leaf extracts. Ind. Crops Prod. 43, 820-826. doi: 10.1016/j.indcrop.2012.08.028

Palou, L. (2009). Control of citrus postharvest diseases by physical means. Tree For. Sci. Biotechnol. 3, 127-142.

Palou, L. (2016). Non-polluting chemical approaches to control citrus postharvest diseases. J Bacteriol Mycol Open Access 2:00019. doi: 10.15406/jbmoa.2016.02.00019

Palou, L. (2018). Postharvest treatments with GRAS salts to control fresh fruit decay. Horticulturae 4:46. doi: 10.3390/horticulturae4040046

Palou, L., Ali, A., Fallik, E., and Romanazzi, G. (2016). GRAS, plant-and animalderived compounds as alternatives to conventional fungicides for the control of postharvest diseases of fresh horticultural produce. Postharvest Biol. Technol. 122, 41-52. doi: 10.1016/j.postharvbio.2016.04.017

Palou, L., Crisosto, C. H., and Garner, D. (2007). Combination of postharvest antifungal chemical treatments and controlled atmosphere storage to control gray mold and improve storability of 'Wonderful' pomegranates. Postharvest Biol. Technol. 43, 133-142. doi: 10.1016/j.postharvbio.2006. 08.013

Palou, L., Smilanick, J. L., and Droby, S. (2008). Alternatives to conventional fungicides for the control of citrus postharvest green and blue moulds. Stewart Postharvest Rev. 2, 1-16. doi: 10.2212/spr.2008.2.2

Palou, L., Smilanick, J. L., Usall, J., and Viñas, I. (2001). Control of postharvest blue and green molds of oranges by hot water, sodium carbonate, and sodium bicarbonate. Plant Dis. 85, 371-376. doi: 10.1094/PDIS.2001.85. 4.371

Palou, L., Usall, J., Munoz, J. A., Smilanick, J. L., and Vinas, I. (2002a). Hot water, sodium carbonate, and sodium bicarbonate for the control of postharvest green and blue molds of clementine mandarins. Postharvest Biol. Technol. 24, 93-96. doi: 10.1016/S0925-5214(01)00178-8

Palou, L., Usall, J., Smilanick, J. L., Aguilar, M. J., and Vinas, I. (2002b). Evaluation of food additives and low-toxicity compounds as alternative chemicals for the control of Penicillium digitatum and Penicillium italicum on citrus fruit. Pest Manag. Sci. 58, 459-466. doi: 10.1002/ps.477 
Palou, L., Valencia-Chamorro, S. A., and Pérez-Gago, M. B. (2015). Antifungal edible coatings for fresh citrus fruit: a review. Coatings 5, 962-986. doi: 10.3390/coatings5040962

Panebianco, S., Vitale, A., Platania, C., Restuccia, C., Polizzi, G., and Cirvilleri, G. (2014). Postharvest efficacy of resistance inducers for the control of green mold on important Sicilian citrus varieties. J. Plant Dis. Protect. 121, 177-183. doi: 10.1007/BF03356507

Panebianco, S., Vitale, A., Polizzi, G., Scala, F., and Cirvilleri, G. (2015). Enhanced control of postharvest citrus fruit decay by means of the combined use of compatible biocontrol agents. Biol. Control 84, 19-27. doi: 10.1016/j.biocontrol.2015.02.001

Papoutsis, K., Mathioudakis, M. M., Hasperué, J. H., and Ziogas, V. (2019). Nonchemical treatments for preventing the postharvest fungal rotting of citrus caused by Penicillium digitatum (green mold) and Penicillium italicum (blue mold). Trends Food Sci. Technol. 86, 479-491. doi: 10.1016/j.tifs.2019.02.053

Parafati, L., Vitale, A., Restuccia, C., and Cirvilleri, G. (2016). The effect of locust bean gum (LBG)-based edible coatings carrying biocontrol yeasts against Penicillium digitatum and Penicillium italicum causal agents of postharvest decay of mandarin fruit. Food Microbiol. 58, 87-94. doi: 10.1016/j.fm.2016.03.014

Parra, J., Ripoll, G., and Orihuel-Iranzo, B. (2014). Potassium sorbate effects on citrus weight loss and decay control. Postharvest Biol. Technol. 96, 7-13. doi: 10.1016/j.postharvbio.2014.04.011

Pelser, P. D. T., and Eckert, J. W. (1977). Constituents of orange juice that stimulate the germination of conidia of Penicillium digitatum. Phytopathology 67, 747-754. doi: 10.1094/Phyto-67-747

Peng, L., Yang, S., Cheng, Y. J., Chen, F., Pan, S., and Fan, G. (2012). Antifungal activity and action mode of pinocembrin from propolis against Penicillium italicum. Food Sci. Biotechnol. 21, 1533-1539. doi: 10.1007/s10068-012-0204-0

Pérez, A. G., Luaces, P., Olmo, M., Sanz, C., and García, J. M. (2005). Effect of intermittent curing on mandarin quality. J. Food Sci. 70, M64-M68. doi: $10.1111 / j .1365-2621.2005 . t b 09048 . x$

Perez, M. F., Ibarreche, J. P., Isas, A. S., Sepulveda, M., Ramallo, J., and Dib, J. R. (2017). Antagonistic yeasts for the biological control of Penicillium digitatum on lemons stored under export conditions. Biol. Control 115, 135-140. doi: 10.1016/j.biocontrol.2017.10.006

Pérez-Alfonso, C. O., Martínez-Romero, D., Zapata, P. J., Serrano, M., Valero, D., and Castillo, S. (2012). The effects of essential oils carvacrol and thymol on growth of Penicillium digitatum and Penicillium italicum involved in lemon decay. Int. J. Food Microbiol. 158, 101-106. doi: 10.1016/j.ijfoodmicro.2012.07.002

Perotti, V. E., Moreno, A. S., Trípodi, K., Del Vecchio, H. A., Meier, G., Bello, F., et al. (2015). Biochemical characterization of the flavedo of heat-treated Valencia orange during postharvest cold storage. Postharvest Biol. Technol. 99, 80-87. doi: 10.1016/j.postharvbio.2014.08.007

Pimenta, R. S., Silva, J. F. M., Coelho, C. M., Morais, P. B., Rosa, C. A., and Corrêa, A. Jr. (2010). Integrated control of Penicillium digitatum by the predacious yeast Saccharomycopsis crataegensis and sodium bicarbonate on oranges. Brazil. J. Microbiol. 41, 404-410. doi: 10.1590/S1517-83822010000200022

Piombo, E., Sela, N., Wisniewski, M., Hoffmann, M., Gullino, M. L., Allard, M. W., et al. (2018). Genome sequence, assembly and characterization of two Metschnikowia fructicola strains used as biocontrol agents of postharvest diseases. Front. Microbiol. 9:593. doi: 10.3389/fmicb.2018.00593

Platania, C., Restuccia, C., Muccilli, S., and Cirvilleri, G. (2012). Efficacy of killer yeasts in the biological control of Penicillium digitatum on Tarocco orange fruits (Citrus sinensis). Food Microbiol. 30, 219-225. doi: $10.1016 /$ j.fm.2011.12.010

Plaza, P., Usall, J., Smilanick, J. L., Lamarca, N., and Viñas, I. (2004a). Combining Pantoea agglomerans (CPA-2) and curing treatments to control established infections of Penicillium digitatum on lemons. J. Food Prot. 67, 781-786. doi: 10.4315/0362-028X-67.4.781

Plaza, P., Usall, J., Torres, R., Abadias, M., Smilanick, J. L., and Viñas, I. (2004b). The use of sodium carbonate to improve curing treatments against green and blue moulds on citrus fruits. Pest Manag. Sci. For. Pestic. Sci. 60, 815-821. doi: $10.1002 / p s .880$

Plaza, P., Usall, J., Torres, R., Lamarca, N., Asensio, A., and Viñas, I. (2003). Control of green and blue mould by curing on oranges during ambient and cold storage. Postharvest Biol. Technol. 28, 195-198. doi: 10.1016/S0925-5214(02)00127-8
Porat, R., Daus, A., Weiss, B., Cohen, L., and Droby, S. (2002). Effects of combining hot water, sodium bicarbonate and biocontrol on postharvest decay of citrus fruit. J. Hortic. Sci. Biotechnol. 77, 441-445. doi: 10.1080/14620316.2002.11511519

Porat, R., Daus, A., Weiss, B., Cohen, L., Fallik, E., and Droby, S. (2000). Reduction of postharvest decay in organic citrus fruit by a short hot water brushing treatment. Postharvest Biol. Technol. 18, 151-157. doi: 10.1016/S0925-5214(99)00065-4

Porat, R., Vinokur, V., Weiss, B., Cohen, L., Daus, A., Goldschmidt, E. E., and Droby, S. (2003). Induction of resistance to Penicillium digitatum in grapefruit by $\beta$-aminobutyric acid. Eur. J. Plant Pathol. 109, 901-907. doi: 10.1023/B:EJPP.0000003624.28975.45

Qasem, J. R. (1996). Aqueous extract effects of sorne common weed species against certain plant pathogenic fungi. Revue Marocaine des Sciences Agronomiques et Vétérinaires 16, 11-19.

Qasem, J. R., and Abu-Blan, H. A. (1995). Antifungal activity of aqueous extracts from some common weed species. Ann. Appl. Biol. 127, 215-219. doi: 10.1111/j.1744-7348.1995.tb06666.x

Ramezani, S., Rahemi, M., and Saharkhiz, M. J. (2009). Biological control of postharvest disease caused by Penicillium digitutum and P. italicum on stored citrus fruits by Shiraz Thyme essential oil. Adv. Environ. Biol. 249-255.

Riggle, J. H., and Klos, E. J. (1972). Relationship of Erwinia herbicola to Erwinia amylovora. Can. J. Bot. 50, 1077-1083. doi: 10.1139/b72-133

Rodov, V., Agar, T., Peretz, J., Nafussi, B., Kim, J. J., and Ben-Yehoshua, S. (2000). Effect of combined application of heat treatments and plastic packaging on keeping quality of 'Oroblanco' fruit (Citrus grandis L. $\times$ C. paradisi Macf.). Postharvest Biol. Technol. 20, 287-294. doi: 10.1016/S0925-5214(00)00129-0

Rodov, V., Ben-Yehoshua, S., Albagli, R., and Fang, D. Q. (1995). Reducing chilling injury and decay of stored citrus fruit by hot water dips. Postharvest Biol. Technol. 5, 119-127. doi: 10.1016/0925-5214(94)00011-G

Rodov, V., Ben-Yehoshua, S., Kim, J. J., Shapiro, B., and Ittah, Y. (1992). Ultraviolet illumination induces scoparone production in kumquat and orange fruit and improves decay resistance. J. Am. Soc. Hortic. Sci. 117, 788-792. doi: 10.21273/JASHS.117.5.788

Roger, F., and Keinath, A. (2010). Biofungicides and Chemicals for Managing Diseases in Organic Vegetable Production. Clemson, SC: Clemson University Cooperative Ext. Information Leaflet, 88.

Rojas-Argudo, C., Palou, L., Bermejo, A., Cano, A., del Río, M. A., and GonzálezMas, M. C. (2012). Effect of X-ray irradiation on nutritional and antifungal bioactive compounds of 'Clemenules' clementine mandarins. Postharvest Biol. Technol. 68, 47-53. doi: 10.1016/j.postharvbio.2012.02.004

Ruiz, V. E., Cerioni, L., Zampini, I. C., Cuello, S., Isla, M. I., Hilal, M., and Rapisarda, V. A. (2017). UV-B radiation on lemons enhances antifungal activity of flavedo extracts against Penicillium digitatum. LWT Food Sci. Technol. 85, 96-103. doi: 10.1016/j.lwt.2017.07.002

Samson, J. A. (1984). Tropical Fruits-Tropical Agricultural Series. New York, NY: Longman Inc.

Sayago, J. E., Ordoñez, R. M., Kovacevich, L. N., Torres, S., and Isla, M. I. (2012). Antifungal activity of extracts of extremophile plants from the Argentine Puna to control citrus postharvest pathogens and green mold. Postharvest Biol. Technol. 67, 19-24. doi: 10.1016/j.postharvbio.2011.12.011

Schirra, M., Agabbio, M., D’Hallewin, G., Pala, M., and Ruggiu, R. (1997) Response of Tarocco oranges to picking date, postharvest hot water dips, and chilling storage temperature. J. Agric. Food Chem. 45, 3216-3220. doi: $10.1021 / \mathrm{j} f 970273 \mathrm{~m}$

Schweiggert, U., Carle, R., and Schieber, A. (2007). Conventional and alternative processes for spice production-a review. Trends Food Sci. Technol. 18, 260-268. doi: 10.1016/j.tifs.2007.01.005

Senaratna, T., Touchell, D., Bunn, E., and Dixon, K. (2000). Acetyl salicylic acid (Aspirin) and salicylic acid induce multiple stress tolerance in bean and tomato plants. Plant Growth Regul. 30, 157-161. doi: 10.1023/A:10063868 00974

Shaat, M. N. M., and Galal, A. A. (2004). Response of citrus fruits to pre-harvest antioxidant spraying and infection with Alternaria fruit rot and green mould. Ann. Agr. Sci. 49, 747-758.

Shao, X., Cao, B., Xu, F., Xie, S., Yu, D., and Wang, H. (2015). Effect of postharvest application of chitosan combined with clove oil against citrus green mold. Postharvest Biol. Technol. 99, 37-43. doi: 10.1016/j.postharvbio.2014.07.014 
Shi, Z., Wang, F., Lu, Y., and Deng, J. (2018). Combination of chitosan and salicylic acid to control postharvest green mold caused by Penicillium digitatum in grapefruit fruit. Sci. Hortic. 233, 54-60. doi: 10.1016/j.scienta.2018.01.039

Shikanga, E., Regnier, T., Combrinck, S., and Botha, B. (2009). Polar Lippia extracts as alternatives for the postharvest control of Guazatine ${ }^{\circledR}$-resistant strains of Penicillium digitatum in citrus. Fruits 64, 75-82. doi: 10.1051/fruits/2009002

Sholberg, P. L. (1998). Fumigation of fruit with short-chain organic acids to reduce the potential of postharvest decay. Plant Dis. 82, 689-693. doi: 10.1094/PDIS.1998.82.6.689

Sitara, U., Hassan, N., and Naseem, J. (2011). Antifungal activity of Aloe vera gel against plant pathogenic fungi. Pak. J. Bot. 43, 2231-2233.

Smilanick, J. L., and Denis-Arrue, R. (1992). Control of green mold of lemons with Pseudomonas species. Plant Dis. 76, 481-485. doi: 10.1094/PD-76-0481

Smilanick, J. L., Mansour, M. F., Gabler, F. M., and Sorenson, D. (2008). Control of citrus postharvest green mold and sour rot by potassium sorbate combined with heat and fungicides. Postharvest Biol. Technol. 47, 226-238. doi: 10.1016/j.postharvbio.2007.06.020

Smilanick, J. L., Mansour, M. F., Margosan, D. A., Gabler, F. M., and Goodwine, W. R. (2005). Influence of $\mathrm{pH}$ and $\mathrm{NaHCO}_{3}$ on effectiveness of imazalil to inhibit germination of Penicillium digitatum and to control postharvest green mold on citrus fruit. Plant Dis. 89, 640-648. doi: 10.1094/PD-89-0640

Smilanick, J. L., Margosan, D. A., Mlikota, F., Usall, J., and Michael, I. F. (1999). Control of citrus green mold by carbonate and bicarbonate salts and the influence of commercial postharvest practices on their efficacy. Plant Dis. 83, 139-145. doi: 10.1094/PDIS.1999.83.2.139

Smilanick, J. L., and Sorenson, D. (2001). Control of postharvest decay of citrus fruit with calcium polysulfide. Postharvest Biol. Technol. 21, 157-168. doi: 10.1016/S0925-5214(00)00142-3

Smilanick, J. L., Sorenson, D., Mansour, M., Aieyabei, J., and Plaza, P. (2003). Impact of a brief postharvest hot water drench treatment on decay, fruit appearance, and microbe populations of California lemons and oranges. Horttechnology 13, 333-338. doi: 10.21273/HORTTECH.13.2.0333

Smoot, J. J., Houck, L. G., and Johnson, H. B. (1971). Market Diseases of Citrus and Other Subtropical Fruits (No. 398). US Agricultural Research Service.

Smoot, J. J., and Melvin, C. F. (1963). "Hot water as a control for citrus decay," in Proceedings of the Florida State Horticultural Society, Vol. 76 (Orlando, FL), $322-327$.

Snowdon, A. L. (1990). A Colour Atlas of Post-Harvest Diseases and Disorders of Fruits and Vegetables. Volume 1: General Introduction and Fruits. Boca Raton, FL: Wolfe Scientific Ltd.

Song, Q. Y., Qi, W. Y., Li, Z. M., Zhao, J., Chen, J. J., and Gao, K. (2011). Antifungal activities of triterpenoids from the roots of Astilbe myriantha Diels. Food Chem. 128, 495-499. doi: 10.1016/j.foodchem.2011.03.059

Soylu, E. M., Tok, F. M., Soylu, S., Kaya, A. D., and Evrendilek, G. A. (2005). Antifungal activities of the essential oils on post-harvest disease agent Penicillium digitatum. Pak. J. Biol. Sci. 8, 25-29. doi: 10.3923/pjbs.2005.25.29

Spadaro, D., and Droby, S. (2016). Development of biocontrol products for postharvest diseases of fruit: the importance of elucidating the mechanisms of action of yeast antagonists. Trends Food Sci. Technol. 47, 39-49. doi: $10.1016 /$ j.tifs.2015.11.003

Spalding, D. H., and Reeder, W. F. (1986). "Effect of hot water and gamma radiation on postharvest decay of grapefruit," in Proceedings of the Annual Meeting of the Florida State Horticultural Society, Vol. 98 (Orlando, FL), 207-208.

Spotts, R. A., Cervantes, L. A., and Facteau, T. J. (2002). Integrated control of brown rot of sweet cherry fruit with a preharvest fungicide, a postharvest yeast, modified atmosphere packaging, and cold storage temperature. Postharvest Biol. Technol. 24, 251-257. doi: 10.1016/S0925-5214(01)0 0155-7

Stange, R. R., and Eckert, J. W. (1994). Influence of postharvest handling and surfactants on control of green mold of lemons by curing. Phytopathology 84, 612-616. doi: 10.1094/Phyto-84-612

Strano, L., Campisano, A., Coco, V., Grimaldi, V., and Catara, A. (2002). Effectiveness of $\mathrm{CaCl}_{2}$ and Tween 80 in enhancing yeast biocontrol activity against Penicillium digitatum on tarocco orange. Plant Prot. Sci 38, 626-628.

Strano, M. C., Calandra, M., Aloisi, V., Rapisarda, P., Strano, T., and Ruberto, G. (2014). Hot water dipping treatments on Tarocco orange fruit and their effects on peel essential oil. Postharvest Biol. Technol. 94, 26-34. doi: $10.1016 /$ j.postharvbio.2014.01.026

Strobel, G. A., Dirkse, E., Sears, J., and Markworth, C. (2001). Volatile antimicrobials from Muscodor albus, a novel endophytic fungus. Microbiology 147, 2943-2950. doi: 10.1099/00221287-147-11-2943

Sui, Y., Wisniewski, M., Droby, S., Norelli, J., and Liu, J. (2016). Recent advances and current status of the use of heat treatments in postharvest disease management systems: is it time to turn up the heat? Trends Food Sci. Technol. 51, 34-40. doi: 10.1016/j.tifs.2016.03.004

Sukorini, H., Sangchote, S., and Khewkhom, N. (2013). Control of postharvest green mold of citrus fruit with yeasts, medicinal plants, and their combination. Postharvest Biol. Technol. 79, 24-31. doi: 10.1016/j.postharvbio.2013.01.001

Suwannarach, N., Kumla, J., Bussaban, B., Nuangmek, W., Matsui, K., and Lumyong, S. (2013). Biofumigation with the endophytic fungus Nodulisporium spp. CMU-UPE34 to control postharvest decay of citrus fruit. Crop Protect. 45, 63-70. doi: 10.1016/j.cropro.2012.11.015

Talibi, I., Askarne, L., Boubaker, H., Boudyach, E. H., Msanda, F., Saadi, B., and Ait Ben Aoumar, A. (2012). Antifungal activity of Moroccan medicinal plants against citrus sour rot agent Geotrichum candidum. Lett. Appl. Microbiol. 55, 155-161. doi: 10.1111/j.1472-765X.2012.03273.x

Talibi, I., Boubaker, H., Boudyach, E. H., and Ait Ben Aoumar, A. (2014). Alternative methods for the control of postharvest citrus diseases. J. Appl. Microbiol. 117, 1-17. doi: 10.1111/jam.12495

Tao, N., Jia, L., and Zhou, H. (2014). Anti-fungal activity of Citrus reticulata Blanco essential oil against Penicillium italicum and Penicillium digitatum. Food Chem. 153, 265-271 doi: 10.1016/j.foodchem.2013.12.070

Tayel, A. A., Moussa, S. H., Salem, M. F., Mazrou, K. E., and El-Tras, W. F. (2016). Control of citrus molds using bioactive coatings incorporated with fungal chitosan/plant extracts composite. J. Sci. Food Agric. 96, 1306-1312. doi: $10.1002 /$ jsfa.7223

Teixidó, N., Usall, J., Palou, L., Asensio, A., Nunes, C., and Viñas, I. (2001). Improving control of green and blue molds of oranges by combining Pantoea agglomerans (CPA-2) and sodium bicarbonate. Eur. J. Plant Pathol. 107, 685-694. doi: 10.1023/A:1011962121067

Terao, D., de Lima Nechet, K., Ponte, M. S., Maia, A. D. H. N., de Almeida Anjos, V. D., and de Almeida Halfeld-Vieira, B. (2017). Physical postharvest treatments combined with antagonistic yeast on the control of orange green mold. Sci. Hortic. 224, 317-323. doi: 10.1016/j.scienta.2017.06.038

Trabelsi, D., Hamdane, A. M., Said, M. B., and Abdrrabba, M. (2016). Chemical composition and antifungal activity of essential oils from flowers, leaves and peels of Tunisian Citrus aurantium against Penicillium digitatum and Penicillium italicum. J. Essential Oil Bearing Plants 19, 1660-1674. doi: 10.1080/0972060X.2016.1141069

Tripathi, P., and Dubey, N. K. (2004). Exploitation of natural products as an alternative strategy to control postharvest fungal rotting of fruit and vegetables. Postharvest Biol. Technol. 32, 235-245. doi: 10.1016/j.postharvbio.2003. 11.005

Tripathi, P., Dubey, N. K., Banerji, R., and Chansouria, J. P. N. (2004). Evaluation of some essential oils as botanical fungitoxicants in management of postharvest rotting of citrus fruits. World J. Microbiol. Biotechnol. 20, 317-321. doi: 10.1023/B:WIBI.0000023844.80464.59

Tripathi, P., Dubey, N. K., and Pandey, V. B. (2002). Kaempferol: the antifungal principle of Acacia nilotica Linn. Del J. Indian Bot. Soc. 81, 51-54.

Tuset, J. J. (1987). Podedumbres de los frutos cítricos. Valencia: Generalitat Valenciano, Chancillería de Agricultura y Pesca. Generalitat Valenciana.

Tyagi, A. K., and Malik, A. (2011). Antimicrobial potential and chemical composition of Mentha piperita oil in liquid and vapour phase against food spoiling microorganisms. Food Control 22, 1707-1714. doi: 10.1016/j.foodcont.2011.04.002

United States Department of Agriculture (2021). Citrus: World Markets and Trade. U.S. Production and Exports Forecast Down Despite Global Gains. United States Department of Agriculture. Foreing Agricultural Service. Available online at: https://apps.fas.usda.gov/psdonline/circulars/citrus.pdf (accessed May 30, 2021).

Usall, J., Ippolito, A., Sisquella, M., and Neri, F. (2016). Physical treatments to control postharvest diseases of fresh fruits and vegetables. Postharvest Biol. Technol. 122, 30-40. doi: 10.1016/j.postharvbio.2016.05.002 
Utama, I. M. S., Wills, R. B., Ben-Yehoshua, S., and Kuek, C. (2002). In vitro efficacy of plant volatiles for inhibiting the growth of fruit and vegetable decay microorganisms. J. Agric. Food Chem. 50, 6371-6377. doi: 10.1021/jf020484d

Valencia-Chamorro, S. A., Palou, L., Del Rio, M. A., and Perez-Gago, M. B. (2008). Inhibition of Penicillium digitatum and Penicillium italicum by hydroxypropyl methylcellulose-lipid edible composite films containing food additives with antifungal properties. J. Agric. Food Chem. 56, 11270-11278. doi: $10.1021 /$ jf802384m

Valencia-Chamorro, S. A., Perez-Gago, M. B., Del Rio, M. A., and Palou, L. (2009). Curative and preventive activity of hydroxypropyl methylcelluloselipid edible composite coatings containing antifungal food additives to control citrus postharvest green and blue molds. J. Agric. Food Chem. 57, 2770-2777. doi: $10.1021 /$ jf803534a

van Hulten, M., Pelser, M., Van Loon, L. C., Pieterse, C. M., and Ton, J. (2006). Costs and benefits of priming for defense in Arabidopsis. Proc. Nat. Acad. Sci. U.S.A. 103, 5602-5607. doi: 10.1073/pnas.0510213103

Velásquez, M. A., Passaro, C. P., Lara-Guzmán, O. J., Álvarez, R., and Londono, J. (2014). Effect of an edible, fungistatic coating on the quality of the 'Valencia'orange during storage and marketing. Acta Hortic. 163-169. doi: 10.17660/ActaHortic.2014.1016.23

Verberne, M. C., Verpoorte, R., Bol, J. F., Mercado-Blanco, J., and Linthorst, H. J. (2000). Overproduction of salicylic acid in plants by bacterial transgenes enhances pathogen resistance. Nat. Biotechnol. 18, 779-783. doi: 10.1038/77347

Villalobos, M. D. C., Serradilla, M. J., Martín, A., Ordiales, E., Ruiz-Moyano, S., and Córdoba, M. D. G. (2016). Antioxidant and antimicrobial activity of natural phenolic extract from defatted soybean flour by-product for stone fruit postharvest application. J. Sci. Food Agric. 96, 2116-2124. doi: 10.1002/jsfa.7327

Vinas, I., Usall, J., Teixidó, N., and Sanchis, V. (1998). Biological control of major postharvest pathogens on apple with Candida sake. Int. J. Food Microbiol. 40, 9-16. doi: 10.1016/S0168-1605(98)00009-9

Waewthongrak, W., Pisuchpen, S., and Leelasuphakul, W. (2015). Effect of Bacillus subtilis and chitosan applications on green mold (Penicilium digitatum Sacc.) decay in citrus fruit. Postharvest Biol. Technol. 99, 44-49. doi: 10.1016/j.postharvbio.2014.07.016

Walters, D. R., Ratsep, J., and Havis, N. D. (2013). Controlling crop diseases using induced resistance: challenges for the future. J. Exp. Bot. 64, 1263-1280. doi: 10.1093/jxb/ert026

Wan, C., Chen, C., Li, M., Yang, Y., Chen, M., and Chen, J. (2017a). Chemical constituents and antifungal activity of Ficus hirta Vahl. fruits. Plants 6:44. doi: 10.3390/plants6040044

Wan, C., Li, P., Chen, C., Peng, X., Li, M., Chen, M., et al. (2017b). Antifungal activity of Ramulus cinnamomi explored by $1 \mathrm{H}-\mathrm{NMR}$ based metabolomics approach. Molecules 22:2237. doi: 10.3390/molecules22122237

Wang, C., Gao, Y., Tao, Y., Wu, X., and Zhibo, C. (2017). Influence of $\gamma$-irradiation on the reactive-oxygen metabolism of blueberry fruit during cold storage. Innovative Food Sci. Emerg. Technolo. 41, 397-403. doi: 10.1016/j.ifset.2017.04.007

Wang, F., Deng, J., Jiao, J., Lu, Y., Yang, L., and Shi, Z. (2019). The combined effects of Carboxymethyl chitosan and Cryptococcus laurentii treatment on postharvest blue mold caused by Penicillium italicum in grapefruit fruit. Sci. Hortic. 253, 35-41. doi: 10.1016/j.scienta.2019.04.031

Wang, H., Yan, Y., Wang, J., Zhang, H., and Qi, W. (2012). Production and characterization of antifungal compounds produced by Lactobacillus plantarum IMAU10014. PLoS ONE 7:e29452. doi: 10.1371/journal.pone.0029452

Wang, J., Cao, S., Wang, L., Wang, X., Jin, P., and Zheng, Y. (2018). Effect of $\beta$-aminobutyric acid on disease resistance against Rhizopus rot in harvested peaches. Front. Microbiol. 9:1505. doi: 10.3389/fmicb.2018.01505

Wang, W., Liu, S., Deng, L., Ming, J., Yao, S., and Zeng, K. (2018). Control of citrus post-harvest green molds, blue molds, and sour rot by the Cecropin A-melittin hybrid peptide BP21. Front. Microbiol. 9:2455. doi: 10.3389/fmicb.2018.02455

Wang, Z., Li, J., Liu, J., Tian, X., Zhang, D., and Wang, Q. (2021a). Management of blue mold (Penicillium italicum) on mandarin fruit with a combination of the yeast, Meyerozyma guilliermondii and an alginate oligosaccharide. Biol. Control 152:104451. doi: 10.1016/j.biocontrol.2020.104451

Wang, Z., Zhong, T., Chen, K., Du, M., Chen, G., Chen, X., et al. (2021b). Antifungal activity of volatile organic compounds produced by Pseudomonas fluorescens ZX and potential biocontrol of blue mold decay on postharvest citrus. Food Control 120:107499. doi: 10.1016/j.foodcont.2020.107499

Whiteside, J. O., Garnsey, S. M., and Timmer, L. W. (1993). Compendium of Citrus Disease. 2nd Edn. Saint Paul, MN: APS Press.

Wilson, C. L., Solar, J. M., El Ghaouth, A., and Wisniewski, M. E. (1997). Rapid evaluation of plant extracts and essential oils for antifungal activity against Botrytis cinerea. Plant Dis. 81, 204-210. doi: 10.1094/PDIS.1997.81.2.204

Wilson, G. F., and Eggemeier, F. T. (1991). "Psychophysiological assessment of workload in multi-task environments," in Multiple-Task Performance, eds G. F. Wilson, and F. Thomas Eggemeier (Bristol, PA: Taylor \& Francis Inc.), 329-360.

Wisniewski, M., Macarisin, D., and Droby, S. (2009). "Challenges and opportunities for the commercialization of postharvest biocontrol," in VI International Postharvest Symposium, Vol. 877 (Antalya), 1577-1582. doi: 10.17660/ActaHortic.2010.877.217

Wisniewski, M. E., and Wilson, C. L. (1992). Biological control of postharvest diseases of fruits and vegetables: recent advances. HortScience 27, 94-98. doi: 10.21273/HORTSCI.27.2.94

Wolken, W. A., Van Loo, W. J., Tramper, J., and Van Der Werf, M. J. (2002). A novel, inducible, citral lyase purified from spores of Penicillium digitatum. Eur. J. Biochem. 269, 5903-5910. doi: 10.1046/j.1432-1033.2002.03312.x

Wong, J. H., Hao, J., Cao, Z., Qiao, M., Xu, H., Bai, Y., and Ng, T. B. (2008), An antifungal protein from Bacillus amyloliquefaciens. J. Appl. Microbiol. 105, 1888-1898. doi: 10.1111/j.1365-2672.2008.03917.x

Wuryatmo, E., Klieber, A., and Scott, E. S. (2003). Inhibition of citrus postharvest pathogens by vapor of citral and related compounds in culture. J. Agric. Food Chem. 51, 2637-2640. doi: 10.1021/jf0261831

Yahyazadeh, M., Omidbaigi, R., Zare, R., and Taheri, H. (2008). Effect of some essential oils on mycelial growth of Penicillium digitatum Sacc. World J. Microbiol. Biotechnol. 24, 1445-1450. doi: 10.1007/s11274-007-9636-8

Yahyazadeh, M., Zare, R., Omidbaigi, R., Faghih-Nasiri, M., and Abbasi, M. (2009). Control of Penicillium decay on citrus fruit using essential oil vapours of thyme or clove inside polyethylene and nano-clay polyethylene films. J. Hortic. Sci. Biotechnol. 84, 403-409. doi: 10.1080/14620316.2009.11512540

Yalpani, N., Enyedi, A. J., León, J., and Raskin, I. (1994). Ultraviolet light and ozone stimulate accumulation of salicylic acid, pathogenesis-related proteins and virus resistance in tobacco. Planta 193, 372-376. doi: 10.1007/BF00201815

Yamaga, I., Kuniga, T., and Aoki, S. (2016). Effect of ultraviolet-B irradiation on control of postharvest decay and scoparone production in noninoculated satsuma mandarin fruit. Trop. Agric. Dev. 60, 283-285. doi: $10.11248 /$ jsta. 60.283

Yamaga, I., Takahashi, T., Ishii, K., Kato, M., and Kobayashi, Y. (2015). Suppression of blue mold symptom development in satsuma mandarin fruits treated by low-intensity blue LED irradiation. Food Sci. Technol. Res. 21, 347-351. doi: $10.3136 /$ fstr.21.347

Yang, S., Liu, L., Li, D., Xia, H., Su, X., Peng, L., and Pan, S. (2016). Use of active extracts of poplar buds against Penicillium italicum and possible modes of action. Food Chem. 196, 610-618. doi: 10.1016/j.foodchem.2015.09.101

Yang, S., Peng, L., Cheng, Y., Chen, F., and Pan, S. (2010). Control of citrus green and blue molds by Chinese propolis. Food Sci. Biotechnol. 19, 1303-1308. doi: 10.1007/s10068-010-0186-8

Yao, H., and Tian, S. (2005). Effects of pre- and post-harvest application of salicylic acid or methyl jasmonate on inducing disease resistance of sweet cherry fruit in storage. Postharvest Biol. Technol. 35, 253-262. doi: 10.1016/j.postharvbio.2004.09.001

Yigit, F., Özcan, M., and Akgül, A. (2000). Inhibitory effect of some spice essential oils on Penicillium digitatum causing postharvest rot in citrus. Grasas y Aceites 51, 237-240. doi: 10.3989/gya.2000.v51.i4.417

Youssef, K., and Hussien, A. (2020). Electrolysed water and salt solutions can reduce green and blue molds while maintain the quality properties of 'Valencia' late oranges. Postharvest Biol. Technol. 159:111025. doi: 10.1016/j.postharvbio.2019.111025

Youssef, K., Ligorio, A., Nigro, F., and Ippolito, A. (2012a). Activity of salts incorporated in wax in controlling postharvest diseases of citrus fruit. Postharvest Biol. Technol. 65, 39-43. doi: 10.1016/j.postharvbio.2011.10.006

Youssef, K., Ligorio, A., Sanzani, S. M., Nigro, F., and Ippolito, A. (2012b). Control of storage diseases of citrus by pre- and postharvest application of salts. Postharvest Biol. Technol. 72, 57-63. doi: 10.1016/j.postharvbio.2012.05.004 
Youssef, K., Sanzani, S. M., Ligorio, A., Ippolito, A., and Terry, L. A. (2014). Sodium carbonate and bicarbonate treatments induce resistance to postharvest green mould on citrus fruit. Postharvest Biol. Technol. 87, 61-69. doi: 10.1016/j.postharvbio.2013.08.006

Yun, Z., Gao, H., Liu, P., Liu, S., Luo, T., Jin, S., et al. (2013). Comparative proteomic and metabolomic profiling of citrus fruit with enhancement of disease resistance by postharvest heat treatment. BMC Plant Biol. 13:44. doi: 10.1186/1471-2229-13-44

Zamani, M., Tehrani, A. S., Ahmadzadeh, M., Hosseininaveh, V., and Mostofy, Y. (2009). Control of Penicillium digitatum on orange fruit combining Pantoea agglomerans with hot sodium bicarbonate dipping. J. Plant Pathol. 437-442.

Zapata, P. J., Navarro, D., Guillén, F., Castillo, S., Martínez-Romero, D., Valero, D., and Serrano, M. (2013). Characterisation of gels from different Aloe spp. as antifungal treatment: potential crops for industrial applications. Industr. Crops Products 42, 223-230. doi: 10.1016/j.indcrop.2012.06.002

Zeng, K., Deng, Y., Ming, J., and Deng, L. (2010). Induction of disease resistance and ROS metabolism in navel oranges by chitosan. Sci. Hortic. 126, 223-228. doi: 10.1016/j.scienta.2010.07.017

Zhang, H., Ma, L., Turner, M., Xu, H., Zheng, X., Dong, Y., and Jiang, S. (2010). Salicylic acid enhances biocontrol efficacy of Rhodotorula glutinis against postharvest Rhizopus rot of strawberries and the possible mechanisms involved. Food Chem. 122, 577-583. doi: 10.1016/j.foodchem.2010.03.013

Zhang, H. Y., Fu, C. X., Zheng, X. D., He, D., Shan, L. J., and Zhan, X. (2004). Effects of Cryptococcus laurentii (Kufferath) Skinner in combination with sodium bicarbonate on biocontrol of postharvest green mold decay of citrus fruit. Bot. Bull. Acad. Sin. Taipei 45, 159-164.

Zhang, H. Y., Zheng, X. D., and Xi, Y. F. (2005). Biological control of postharvest blue mold of oranges by Cryptococcus laurentii (Kufferath) Skinner. Biocontrol 50, 331-342. doi: 10.1007/s10526-004-0452-x

Zhang, J., and Swingle, P. P. (2005). Effects of curing on green mold and stem-end rot of citrus fruit and its potential application under Florida packing system. Plant Dis. 89, 834-840. doi: 10.1094/PD-89-0834

Zhang, X., Guo, Y., Guo, L., Jiang, H., and Ji, Q. (2018). In vitro evaluation of antioxidant and antimicrobial activities of Melaleuca alternifolia essential oil. Biomed Res. Int. 2018:2396109. doi: 10.1155/2018/2396109

Zhang, Y., Niu, Y., Luo, Y., Ge, M., Yang, T., Yu, L. L., and Wang, Q. (2014). Fabrication, characterization and antimicrobial activities of thymol-loaded zein nanoparticles stabilized by sodium caseinate-chitosan hydrochloride double layers. Food Chem. 142, 269-275. doi: 10.1016/j.foodchem.2013. 07.058

Zheng, X. D., Zhang, H. Y., and Sun, P. (2005). Biological control of postharvest green mold decay of oranges by Rhodotorula glutinis. Eur. Food Res. Technol. 220, 353-357. doi: 10.1007/s00217-004-1056-5
Zhou, M., and Wang, W. (2018). Recent advances in synthetic chemical inducers of plant immunity. Front. Plant Sci. 9:1613. doi: 10.3389/fpls.2018. 01613

Zhou, Y., Ma, J., Xie, J., Deng, L., Yao, S., and Zeng, K. (2018). Transcriptomic and biochemical analysis of highlighted induction of phenylpropanoid pathway metabolism of citrus fruit in response to salicylic acid, Pichia membranaefaciens and oligochitosan. Postharvest Biol. Technol. 142, 81-92. doi: 10.1016/j.postharvbio.2018.01.021

Zhou, Y., Ming, J., Deng, L., and Zeng, K. (2014). Effect of Pichia membranaefaciens in combination with salicylic acid on postharvest blue and green mold decay in citrus fruits. Biol. Control 74, 21-29. doi: 10.1016/j.biocontrol.2014. 03.007

Zhu, C., Sheng, D., Wu, X., Wang, M., Hu, X., Li, H., and Yu, D. (2017). Identification of secondary metabolite biosynthetic gene clusters associated with the infection of citrus fruit by Penicillium digitatum. Postharvest Biol. Technol. 134, 17-21. doi: 10.1016/j.postharvbio.2017.07.011

Zhu, H., Zhao, L., Zhang, X., Foku, J. M., Li, J., Hu, W., and Zhang, H. (2019). Efficacy of Yarrowia lipolytica in the biocontrol of green mold and blue mold in Citrus reticulata and the mechanisms involved. Biol. Control 139:104096. doi: 10.1016/j.biocontrol.2019.104096

Zhu, R., Lu, L., Guo, J., Lu, H., Abudureheman, N., Yu, T., and Zheng, X. (2013). Postharvest control of green mold decay of citrus fruit using combined treatment with sodium bicarbonate and Rhodosporidium paludigenum. Food Bioproc. Technol. 6, 2925-2930. doi: 10.1007/s11947-0120863-0

Conflict of Interest: The author declares that the research was conducted in the absence of any commercial or financial relationships that could be construed as a potential conflict of interest.

Publisher's Note: All claims expressed in this article are solely those of the authors and do not necessarily represent those of their affiliated organizations, or those of the publisher, the editors and the reviewers. Any product that may be evaluated in this article, or claim that may be made by its manufacturer, is not guaranteed or endorsed by the publisher.

Copyright $\odot 2022$ Bhatta. This is an open-access article distributed under the terms of the Creative Commons Attribution License (CC BY). The use, distribution or reproduction in other forums is permitted, provided the original author(s) and the copyright owner(s) are credited and that the original publication in this journal is cited, in accordance with accepted academic practice. No use, distribution or reproduction is permitted which does not comply with these terms. 